\title{
Effect of Alkyl Chain Branching on the Physicochemical Properties of Imidazolium-Based Ionic Liquids
}

Lianjie Xue, Eshan Gurung, George Tamas, Yung P. Koh, Michael Shadeck, Sindee L. Simon,

Mark Maroncelli, and Edward L. Quitevis

\section{Supporting Information}

\section{Table of Contents}

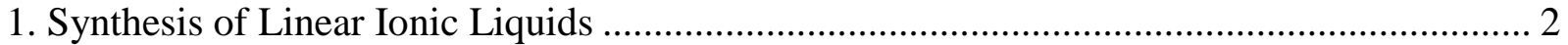

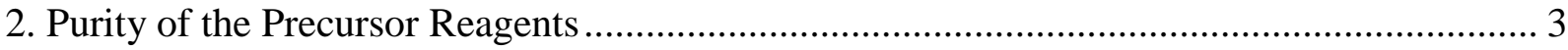

3. Sample Description Table of Ionic Liquids .............................................................. 4

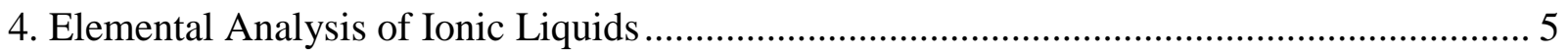

5. Electrospray Ionization Mass Spectra of Ionic Liquids ............................................ 6

6. NMR Spectra of Branched Ionic Liquids $\left[(\mathrm{N}-2) \mathrm{mC}_{\mathrm{N}-1} \mathrm{C}_{1} \mathrm{im}\right]\left[\mathrm{NTf}_{2}\right]$ with $\mathrm{N}=3-7 \ldots \ldots \ldots \ldots . . .18$

7. Calibration of Density Meter and Viscosity-Induced Error Correction ............................... 24

8. Determination of Nominal Standard Uncertainty in Density Measurements. .................... 28

9. Comparison of Densities (Current Work vs. NIST Database) at 298.15 K. ..................... 29

10. Plots of Density vs. Temperature (Current Work and NIST Database).......................... 30

11. Comparison of Melting Temperatures and Enthalpies of Fusion (Current Work vs. NIST

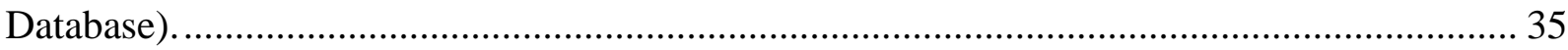

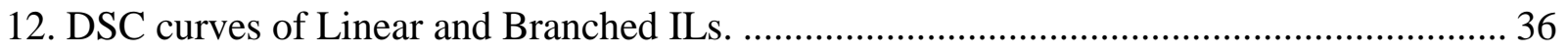

13. Comparison of Viscosities at 298.15 K (Current Work and NIST database)................... 38

14. Plots of Viscosity vs. Temperature (Current work and NIST Database).......................... 39

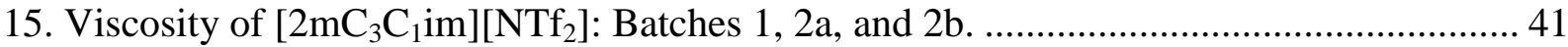

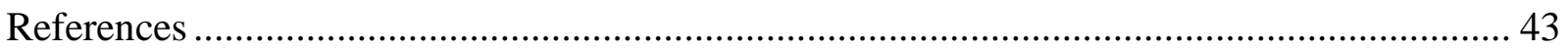




\section{Synthesis of Linear Ionic Liquids}

(Generic procedure for the synthesis of the 1-(n-alkyl)-3-methylimidazolium

bis[(trifluoromethane)sulfonyl]amide $\left[\mathrm{C}_{\mathrm{N}} \mathrm{C}_{1} \mathrm{im}\right]\left[\mathrm{NTf}_{2}\right]$ ionic liquids.)

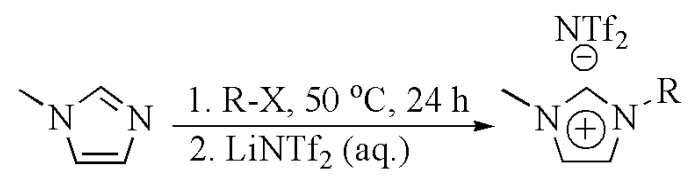

Scheme S1. Generic synthesis of $\left[\mathrm{C}_{\mathrm{N}} \mathrm{C}_{1} \mathrm{im}\right]\left[\mathrm{NTf}_{2}\right]$ with $\mathrm{N}=3-7$.

The ionic liquids (ILs) were synthesized using modified procedures published elsewhere and summarized in the generic Scheme $1 .{ }^{1-2}$ The quaternization step was performed at $50{ }^{\circ} \mathrm{C}$, adding a slight excess of the corresponding alkyl bromide (i.e., 1.05 eq.) to ensure complete consumption of 1-methylimidazole. The unreacted halide was removed by repeated washing of the IL with a 1:3(v/v) mixture of dichloromethane and hexanes. The decolorization of the IL was accomplished at its bromide stage according to an in-house developed protocol (vide supra). The metathesis was performed in presence of aqueous $\operatorname{LiNTf}_{2} .{ }^{3}$ The lithium bromide formed was removed by repeated washing with triple deionized water until passing the silver nitrate test. The excess water was removed via benzene azeotrope, using a Dean-Stark trap. Further drying was carried out under high vacuum at $40{ }^{\circ} \mathrm{C}$ and having the water content assessed by Karl-Fischer coulometric titration. All final products were colorless liquids at room temperature. 


\section{Purity of the Precursor Reagents}

The purities of the precursors for the preparation of the IL samples are listed in Table S1.

Table S1. Purity and Source of Precursors in the Synthesis of Branched and Linear ILs.

\begin{tabular}{|l|l|l|l|}
\hline Name of reagents & Formula & Source & Purity \\
\hline 1-bromopropane & $\mathrm{CH}_{3} \mathrm{CH}_{2} \mathrm{CH}_{2} \mathrm{Br}$ & Aldrich Chem. Co. & 0.99 \\
\hline 1-bromobutane & $\mathrm{CH}_{3}\left(\mathrm{CH}_{2}\right)_{2} \mathrm{CH}_{2} \mathrm{Br}$ & ACROS ORGANICS & 0.99 \\
\hline 1-bromopentane & $\mathrm{CH}_{3}\left(\mathrm{CH}_{2}\right)_{3} \mathrm{CH}_{2} \mathrm{Br}$ & ACROS ORGANICS & 0.98 \\
\hline 1-bromohexane & $\mathrm{CH}_{3}\left(\mathrm{CH}_{2}\right)_{4} \mathrm{CH}_{2} \mathrm{Br}$ & ACROS ORGANICS & 0.99 \\
\hline 1-bromoheptane & $\mathrm{CH}_{3}\left(\mathrm{CH}_{2}\right)_{5} \mathrm{CH}_{2} \mathrm{Br}$ & Aldrich Chemical Co. & 0.99 \\
\hline 2-bromopropane & $\mathrm{CH}_{3} \mathrm{CH}_{2} \mathrm{BrCH}_{3}$ & ACROS ORGANICS & 0.99 \\
\hline 1-bromo-2-methylpropane & $\mathrm{CH}_{2} \mathrm{BrCH}_{2}\left(\mathrm{CH}_{3}\right)_{2}$ & Alfa Aesar & 0.98 \\
\hline 1-bromo-3-methylbutane & $\mathrm{CH}_{2} \mathrm{BrCH}_{2} \mathrm{CH}_{2}\left(\mathrm{CH}_{3}\right)_{2}$ & Aldrich Chem. Co. & 0.96 \\
\hline 1-bromo-4-methylpentane & $\mathrm{CH}_{2} \mathrm{Br}_{\left(-\mathrm{CH}_{2}\right)_{3}\left(\mathrm{CH}_{3}\right)_{2}}$ & Sigma-Aldrich & 0.97 \\
\hline 1-bromo-5-methylhexane & $\mathrm{CH}_{2} \mathrm{Br}_{(}\left(\mathrm{CH}_{2}\right)_{4}\left(\mathrm{CH}_{3}\right)_{2}$ & Alfa Aesar & 0.97 \\
\hline 1-methylimidazole & $\mathrm{CH}_{3}\left(\mathrm{C}_{3} \mathrm{H}_{3} \mathrm{~N}_{2}\right)$ & Aldrich Chem. Co. & 0.99 \\
\hline
\end{tabular}




\section{Sample Description Table of Ionic Liquids}

Table S2. Sample Description of the Linear $\left[\mathrm{C}_{\mathrm{N}} \mathrm{C}_{1} \mathrm{im}\right]\left[\mathrm{NTf} \mathrm{f}_{2}\right]$ and branched $\left[(\mathrm{N}-2) \mathrm{mC}_{\mathrm{N}-1} \mathrm{C}_{1} \mathrm{im}\right]\left[\mathrm{NTf} \mathrm{IL}_{2}\right]$ with $\mathrm{N}=3-7$ Investigated in this Study.

\begin{tabular}{|c|c|c|c|c|c|}
\hline Ionic Liquid Description & $\begin{array}{l}\text { Chemical } \\
\text { Formula }\end{array}$ & $\begin{array}{c}\text { Purification } \\
\text { Method }\end{array}$ & Purity & $\begin{array}{c}\text { Water Mole } \\
\text { Fraction }\end{array}$ & Analysis Method \\
\hline $\begin{array}{l}\text { 1-propyl-3-methylimidazolium } \\
\text { bis[(trifluoromethane)sulfonyl]amide }\end{array}$ & $\mathrm{C}_{9} \mathrm{H}_{13} \mathrm{~F}_{6} \mathrm{~N}_{3} \mathrm{O}_{4} \mathrm{~S}_{2}$ & \multirow{10}{*}{$\begin{array}{l}\text { Column Filtration; } \\
\text { Benzene Azeotrope; } \\
\text { Decolorization with } \\
\text { Activated Charcoal }\end{array}$} & 0.999 & 0.0007 & \multirow{10}{*}{$\begin{array}{c}\text { NMR } \\
\text { ESI-MS, } \\
\text { Elemental } \\
\text { Analysis, } \\
\text { Karl-Fischer } \\
\text { Titration }\end{array}$} \\
\hline $\begin{array}{l}\text { 1-butyl-3-methylimidazolium } \\
\text { bis[(trifluoromethane)sulfonyl]amide }\end{array}$ & $\mathrm{C}_{10} \mathrm{H}_{15} \mathrm{~F}_{6} \mathrm{~N}_{3} \mathrm{O}_{4} \mathrm{~S}_{2}$ & & 0.997 & 0.0033 & \\
\hline $\begin{array}{l}\text { 1-pentyl-3-methylimidazolium } \\
\text { bis[(trifluoromethane)sulfonyl]amide }\end{array}$ & $\mathrm{C}_{11} \mathrm{H}_{17} \mathrm{~F}_{6} \mathrm{~N}_{3} \mathrm{O}_{4} \mathrm{~S}_{2}$ & & 0.996 & 0.0044 & \\
\hline $\begin{array}{l}\text { 1-hexyl-3-methylimidazolium } \\
\text { bis[(trifluoromethane)sulfonyl]amide }\end{array}$ & $\mathrm{C}_{12} \mathrm{H}_{19} \mathrm{~F}_{6} \mathrm{~N}_{3} \mathrm{O}_{4} \mathrm{~S}_{2}$ & & 0.998 & 0.0020 & \\
\hline $\begin{array}{l}\text { 1-heptyl-3-methylimidazolium } \\
\text { bis[(trifluoromethane)sulfonyl]amide }\end{array}$ & $\mathrm{C}_{13} \mathrm{H}_{21} \mathrm{~F}_{6} \mathrm{~N}_{3} \mathrm{O}_{4} \mathrm{~S}_{2}$ & & 0.999 & 0.0013 & \\
\hline $\begin{array}{l}\text { 1-(1-methylethyl)-3-methylimidazolium } \\
\text { bis[(trifluoromethane)sulfonyl]amide }\end{array}$ & $\mathrm{C}_{9} \mathrm{H}_{13} \mathrm{~F}_{6} \mathrm{~N}_{3} \mathrm{O}_{4} \mathrm{~S}_{2}$ & & 0.998 & 0.0016 & \\
\hline $\begin{array}{l}\text { 1-(2-methylpropyl)-3-methylimidazolium } \\
\text { bis[(trifluoromethane)sulfonyl]amide }\end{array}$ & $\mathrm{C}_{10} \mathrm{H}_{15} \mathrm{~F}_{6} \mathrm{~N}_{3} \mathrm{O}_{4} \mathrm{~S}_{2}$ & & 0.999 & 0.0012 & \\
\hline $\begin{array}{l}\text { 1-(3-methylbutyl)-3-methylimidazolium } \\
\text { bis[(trifluoromethane)sulfonyl]amide }\end{array}$ & $\mathrm{C}_{11} \mathrm{H}_{17} \mathrm{~F}_{6} \mathrm{~N}_{3} \mathrm{O}_{4} \mathrm{~S}_{2}$ & & 0.998 & 0.0020 & \\
\hline $\begin{array}{l}\text { 1-(4-methypentyl)-3-methylimidazolium } \\
\text { bis[(trifluoromethane)sulfonyl]amide }\end{array}$ & $\mathrm{C}_{13} \mathrm{H}_{19} \mathrm{~F}_{6} \mathrm{~N}_{3} \mathrm{O}_{4} \mathrm{~S}_{2}$ & & 0.999 & 0.0009 & \\
\hline $\begin{array}{l}\text { 1-(5-methylhexyl)-3-methylimidazolium } \\
\text { bis[(trifluoromethane)sulfonyl]amide }\end{array}$ & $\mathrm{C}_{15} \mathrm{H}_{21} \mathrm{~F}_{6} \mathrm{~N}_{3} \mathrm{O}_{4} \mathrm{~S}_{2}$ & & 0.998 & 0.0021 & \\
\hline
\end{tabular}

${ }^{a}$ Electrospray Ionisation Mass Spectrometry (Thermo Scientific LCQ Fleet ESI and Ion Trap Mass Spectrometer). ${ }^{\mathrm{b}}$ Perkin Elmer CHNS/O 2400 Analyzer 


\section{Elemental Analysis of Ionic Liquids}

Table S3. Calculated and Experimentally Measured Carbon Weight Percent in Ionic Liquid Samples. $^{\text {a.b }}$

\begin{tabular}{|c|c|c|c|c|c|}
\hline & F.W. & No. of C atoms in ILs & Cal. Wt\% & Exp. Wt\% & \% Dev. \\
\hline$\left[1 \mathrm{mC}_{2} \mathrm{C}_{1} \mathrm{im}\right]\left[\mathrm{NTf}_{2}\right]$ & 405.34 & 9 & 26.66872 & 26.7 & 0.1 \\
\hline$\left[2 \mathrm{mC}_{3} \mathrm{C}_{1} \mathrm{im}\right]\left[\mathrm{NTf}_{2}\right]$ & 419.367 & 10 & 28.64078 & 28.67 & 0.1 \\
\hline$\left[3 \mathrm{mC}_{4} \mathrm{C}_{1} \mathrm{im}\right]\left[\mathrm{NTf}_{2}\right]$ & 433.394 & 11 & 30.48519 & 30.47 & -0.05 \\
\hline$\left[4 \mathrm{mC}_{5} \mathrm{C}_{1} \mathrm{im}\right]\left[\mathrm{NTf}_{2}\right]$ & 447.421 & 12 & 32.21396 & 32.19 & -0.07 \\
\hline$\left[5 \mathrm{mC}_{6} \mathrm{C}_{1} \mathrm{im}\right]\left[\mathrm{NTf}_{2}\right]$ & 461.448 & 13 & 33.83762 & 33.94 & 0.3 \\
\hline$\left[\mathrm{C}_{3} \mathrm{C}_{1} \mathrm{im}\right]\left[\mathrm{NTf}_{2}\right]$ & 405.34 & 9 & 26.66872 & 26.685 & 0.06 \\
\hline$\left[\mathrm{C}_{4} \mathrm{C}_{1} \mathrm{im}\right]\left[\mathrm{NTf}_{2}\right]$ & 419.367 & 10 & 28.64078 & 28.64 & -0.003 \\
\hline$\left[\mathrm{C}_{5} \mathrm{C}_{1} \mathrm{im}\right]\left[\mathrm{NTf}_{2}\right]$ & 433.394 & 11 & 30.48519 & 30.55 & 0.2 \\
\hline$\left[\mathrm{C}_{6} \mathrm{C}_{1} \mathrm{im}\right]\left[\mathrm{NTf}_{2}\right]$ & 447.421 & 12 & 32.21396 & 32.3 & 0.3 \\
\hline$\left[\mathrm{C}_{7} \mathrm{C}_{1} \mathrm{im}\right]\left[\mathrm{NTf}_{2}\right]$ & 461.448 & 13 & 33.83762 & 33.81 & -0.08 \\
\hline
\end{tabular}

${ }^{\mathrm{a}}$ Perkin Elmer CHNS/O 2400 Analyzer; ${ }^{b}$ Percent deviation of Exp. Wt\% from Cal. Wt\%. 


\section{Electrospray Ionization Mass Spectra of Ionic Liquids}

Assignments of the $\mathrm{m} / \mathrm{z}$ peaks in ESI-MS spectra are as below:

$1 \mathrm{mC}_{2} \mathrm{C}_{1}$ Positive 125.0: $\left[1 \mathrm{mC}_{2} \mathrm{C}_{1} \mathrm{im}\right]^{+}, 529.9: 2\left[1 \mathrm{mC}_{2} \mathrm{C}_{1} \mathrm{im}\right]^{+}+\left[\mathrm{NTf}_{2}\right]^{-}$.

Negative 147.2: in-source fragmentation, 280.2: $\left[\mathrm{NTf}_{2}\right]^{-}$.

$2 \mathrm{mC}_{3} \mathrm{C}_{1}$ Positive: 139.1: $\left[2 \mathrm{mC}_{3} \mathrm{C}_{1} \mathrm{im}\right]^{+}$, 557.6: $2\left[2 \mathrm{mC}_{3} \mathrm{C}_{1} \mathrm{im}\right]^{+}+\left[\mathrm{NTf}_{2}\right]^{-}$.

Negative 147.2: in-source fragmentation, 280.2: [ $\left.\mathrm{NTf}_{2}\right]^{-}$.

$3 \mathrm{mC}_{4} \mathrm{C}_{1}$ Positive 153.1: $\left[3 \mathrm{mC}_{4} \mathrm{C}_{1} \mathrm{im}\right]^{+}$, 585.6: $2\left[3 \mathrm{mC}_{4} \mathrm{C}_{1} \mathrm{im}\right]^{+}+\left[\mathrm{NTf}_{2}\right]^{-}$.

Negative 147.2: in-source fragmentation, 280.2: [ $\left.\mathrm{NTf}_{2}\right]^{-}$.

$4 \mathrm{mC}_{5} \mathrm{C}_{1}$ Positive 167.1: $\left[4 \mathrm{mC}_{5} \mathrm{C}_{1} \mathrm{im}\right]^{+}, 613.7: 2\left[4 \mathrm{mC}_{5} \mathrm{C}_{1} \mathrm{im}\right]^{+}+\left[\mathrm{NTf}_{2}\right]^{-}$.

Negative 147.2: in-source fragmentation, 280.2: $\left[\mathrm{NTf}_{2}\right]^{-}$.

5mC $\mathrm{m}_{6} \mathrm{C}_{1}$ Positive 181.2: $\left[5 \mathrm{mC}_{6} \mathrm{C}_{1} \mathrm{im}\right]^{+}, 641.76: 2\left[5 \mathrm{mC}_{6} \mathrm{C}_{1} \mathrm{im}\right]^{+}+\left[\mathrm{NTf}_{2}\right]^{-}$.

Negative 147.2: in-source fragmentation, 280.2: $\left[\mathrm{NTf}_{2}\right]^{-}$.

$\mathrm{C}_{3} \mathrm{C}_{1} \quad$ Positive 125.1: $\left[\mathrm{C}_{3} \mathrm{C}_{1} \text { im }\right]^{+}$.

Negative 147.2: in-source fragmentation, 280.2: [ $\left.\mathrm{NTf}_{2}\right]^{-}$.

$\mathrm{C}_{4} \mathrm{C}_{1} \quad$ Positive 139.1: $\left[\mathrm{C}_{4} \mathrm{C}_{1} \mathrm{im}\right]^{+}$, 557.9: $2\left[\mathrm{C}_{4} \mathrm{C}_{1} \mathrm{im}\right]^{+}+\left[\mathrm{NTf}_{2}\right]^{-}$.

Negative 147.2: in-source fragmentation, 280.2: $\left[\mathrm{NTf}_{2}\right]^{-}$.

$\mathrm{C}_{5} \mathrm{C}_{1} \quad$ Positive 153.1: $\left[\mathrm{C}_{5} \mathrm{C}_{1} \mathrm{im}\right]^{+}$, 585.7: $2\left[\mathrm{C}_{5} \mathrm{C}_{1} \mathrm{im}\right]^{+}+\left[\mathrm{NTf}_{2}\right]^{-}$.

Negative 147.2: in-source fragmentation, 280.2: $\left[\mathrm{NTf}_{2}\right]^{-}, 726.7:\left[\mathrm{C}_{6} \mathrm{C}_{1} \mathrm{im}\right]^{+}+2\left[\mathrm{NTf}_{2}\right]^{-}$, $\left[\mathrm{C}_{6} \mathrm{C}_{1} \mathrm{im}\right]^{+}$from leftover from running of $\left[\mathrm{C}_{6} \mathrm{C}_{1} \mathrm{im}\right]\left[\mathrm{NTf}_{2}\right]$.

$\mathrm{C}_{6} \mathrm{C}_{1} \quad$ Positive 167.13: $\left[\mathrm{C}_{6} \mathrm{C}_{1} \mathrm{im}\right]^{+}$, 614.0: $2\left[\mathrm{C}_{6} \mathrm{C}_{1} \mathrm{im}\right]^{+}+\left[\mathrm{NTf}_{2}\right]^{-}$.

Negative 147.2: in-source fragmentation, 280.2: $\left[\mathrm{NTf}_{2}\right]^{-}, 726.7:\left[\mathrm{C}_{6} \mathrm{C}_{1} \mathrm{im}^{+}+2\left[\mathrm{NTf}_{2}\right]^{-}\right.$.

$\mathrm{C}_{7} \mathrm{C}_{1} \quad$ Positive 181.16: $\left[\mathrm{C}_{7} \mathrm{C}_{1} \mathrm{im}\right]^{+}$, 642.0: $2\left[\mathrm{C}_{7} \mathrm{C}_{1} \mathrm{im}\right]^{+}+\left[\mathrm{NTf}_{2}\right]^{-}$.

Negative 147.2: in-source fragmentation, 280.2: $\left[\mathrm{NTf}_{2}\right]^{-}, 740.8:\left[\mathrm{C}_{7} \mathrm{C}_{1} \mathrm{im}\right]^{+}+2\left[\mathrm{NTf}_{2}\right]^{-}$, 380.3: from system background. 
15102701_Pos_1mC2C1 \#734-772 RT: 2.57-2.74 AV: 39 NL: $1.09 E 4$

T: TMS + c ESI Full ms [50.00-2000.00]
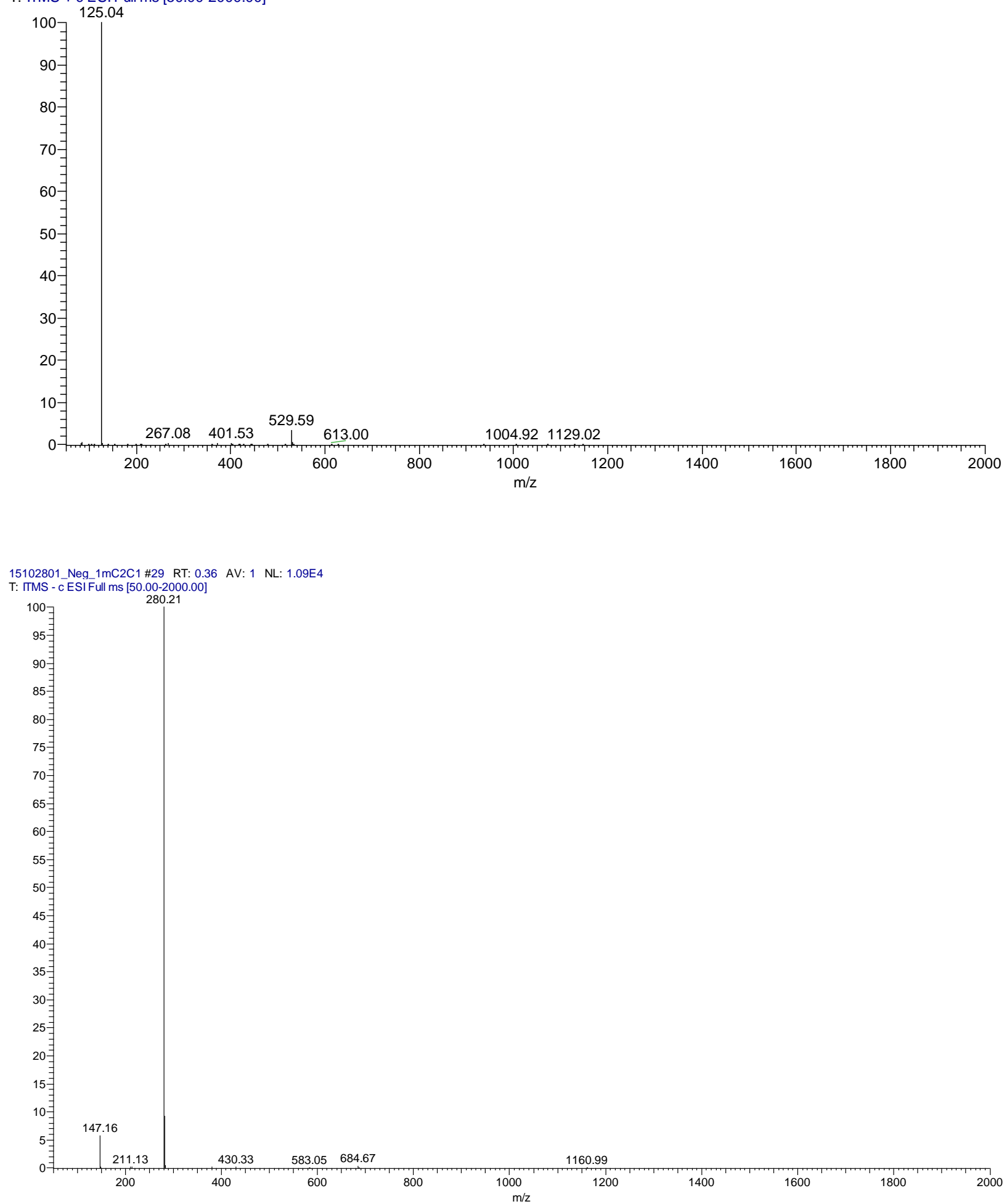


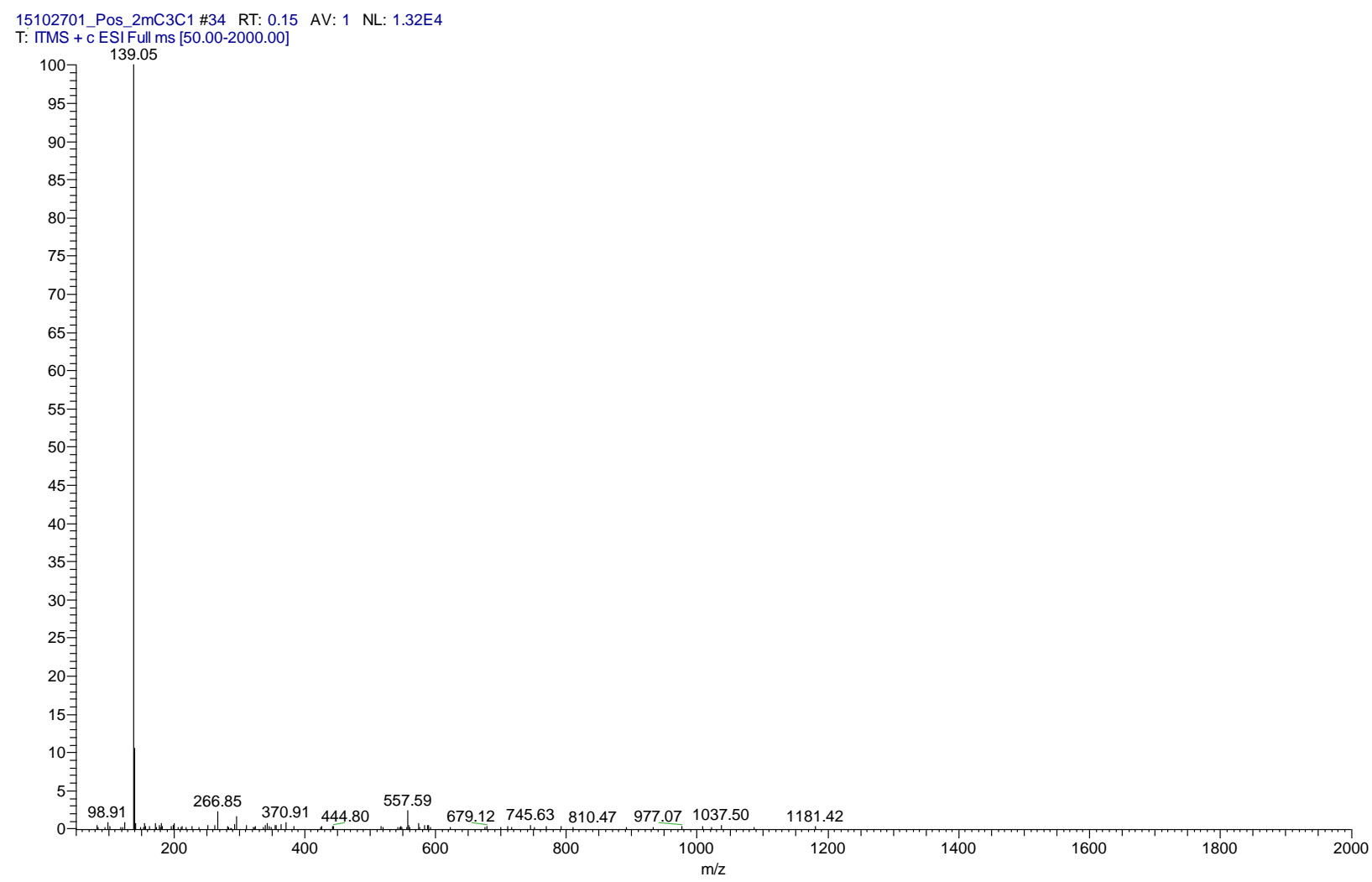

15102702 Neg 2mC3C1 \#29 RT: 0.36 AV: 1 NL: 1.66E4

T: TTMS - c ESI Full ms [50.00-2000.00]

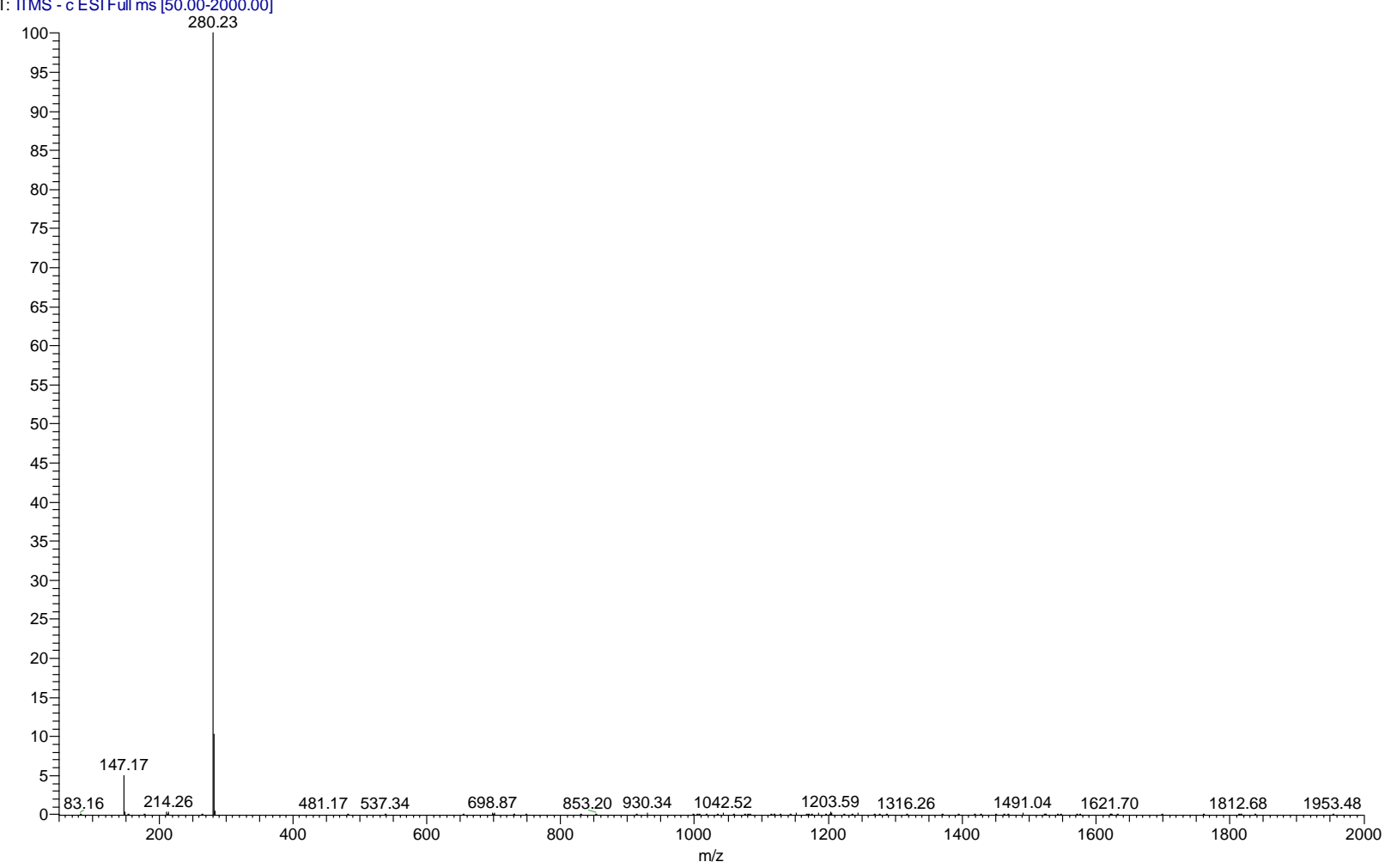




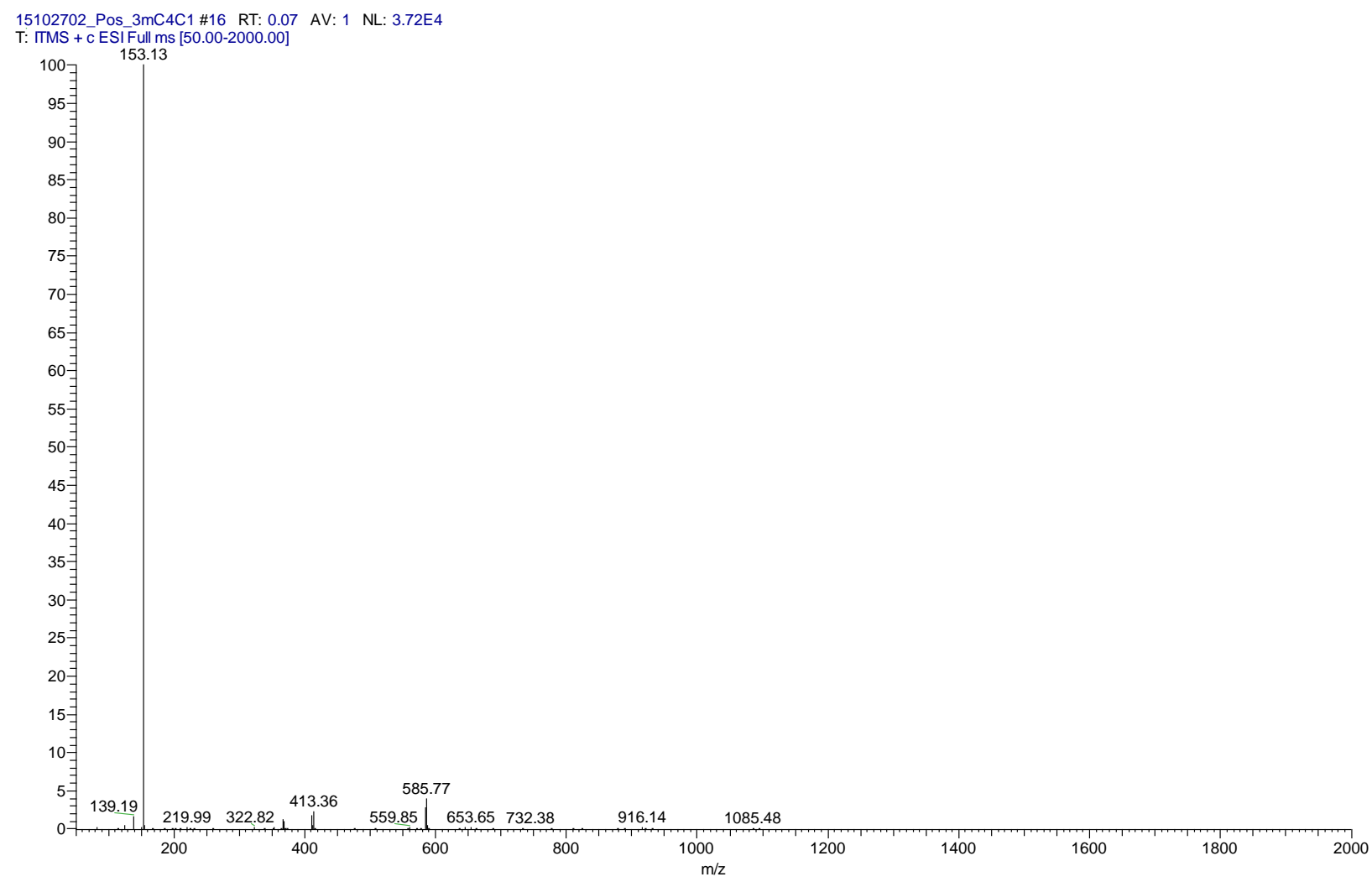

15102702_Neg_3mC4C1\#102 RT: 1.28 AV: 1 NL: 1.87E4

T: TTMS - c ESI Full ms [50.00-2000.00]

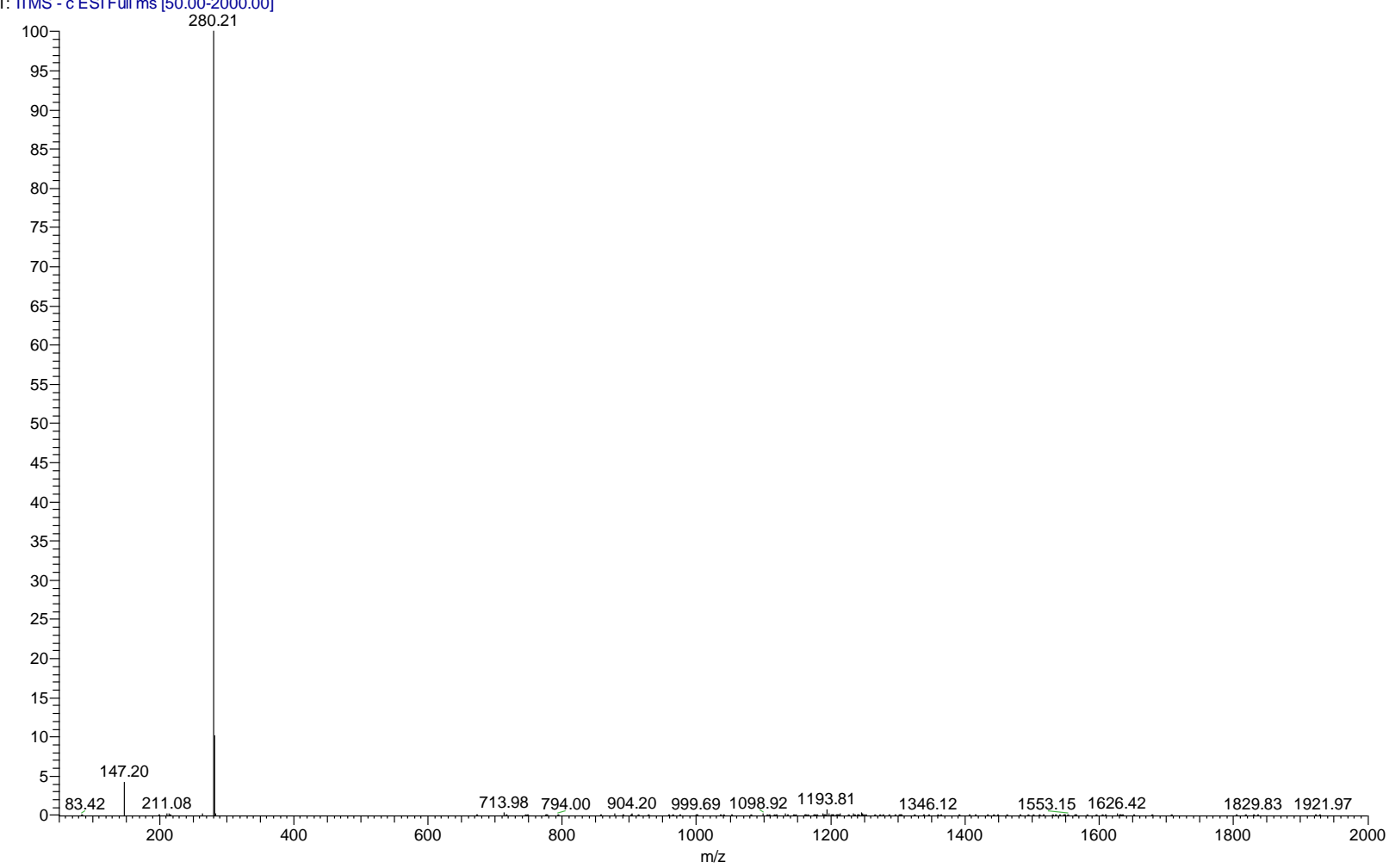




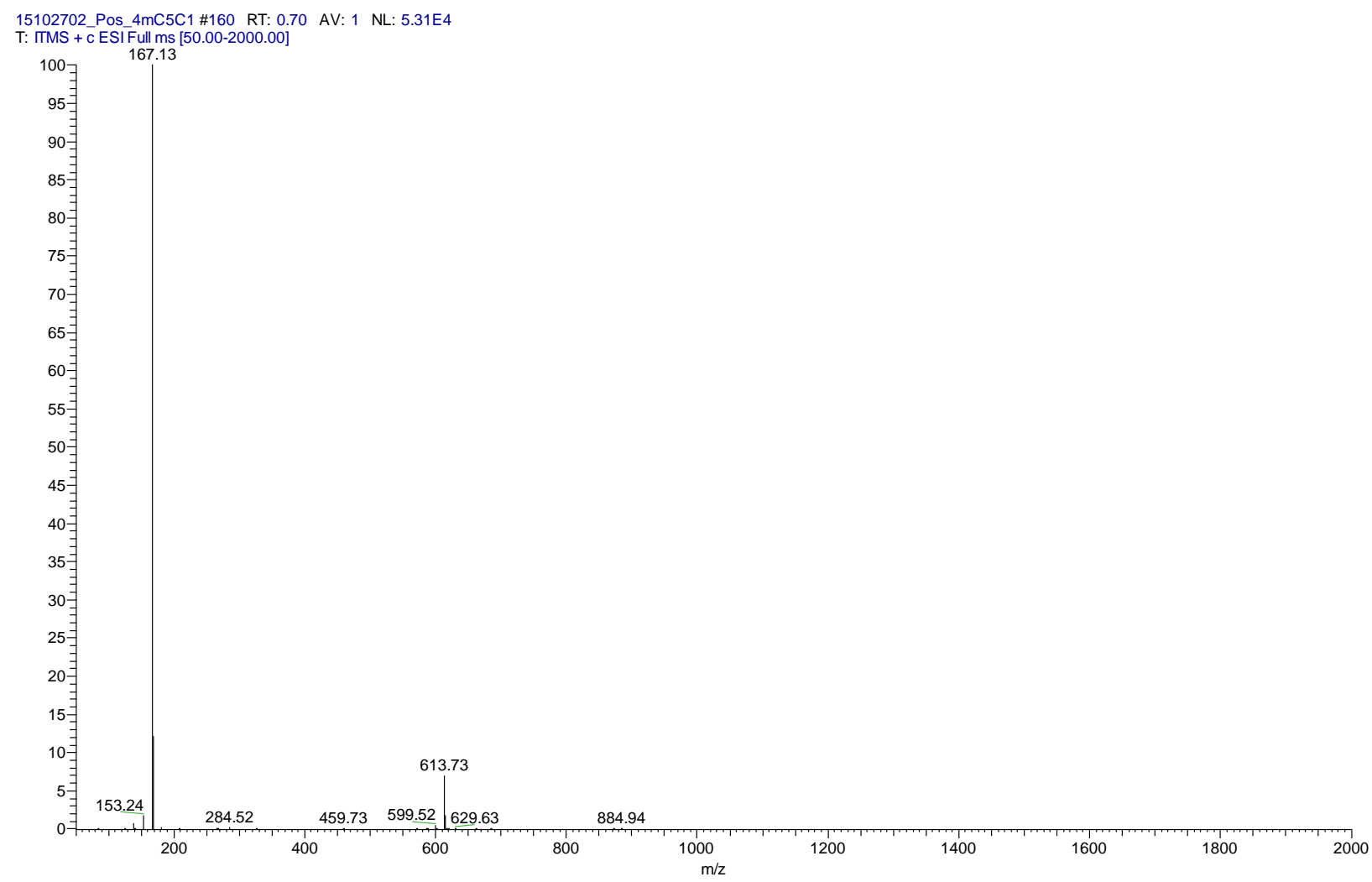

15102702 Neg 4mC5C1 \#94 RT: 1.18 AV: 1 NL: 1.95E4

T: TMS - c ESI Full ms [50.00-2000.00]

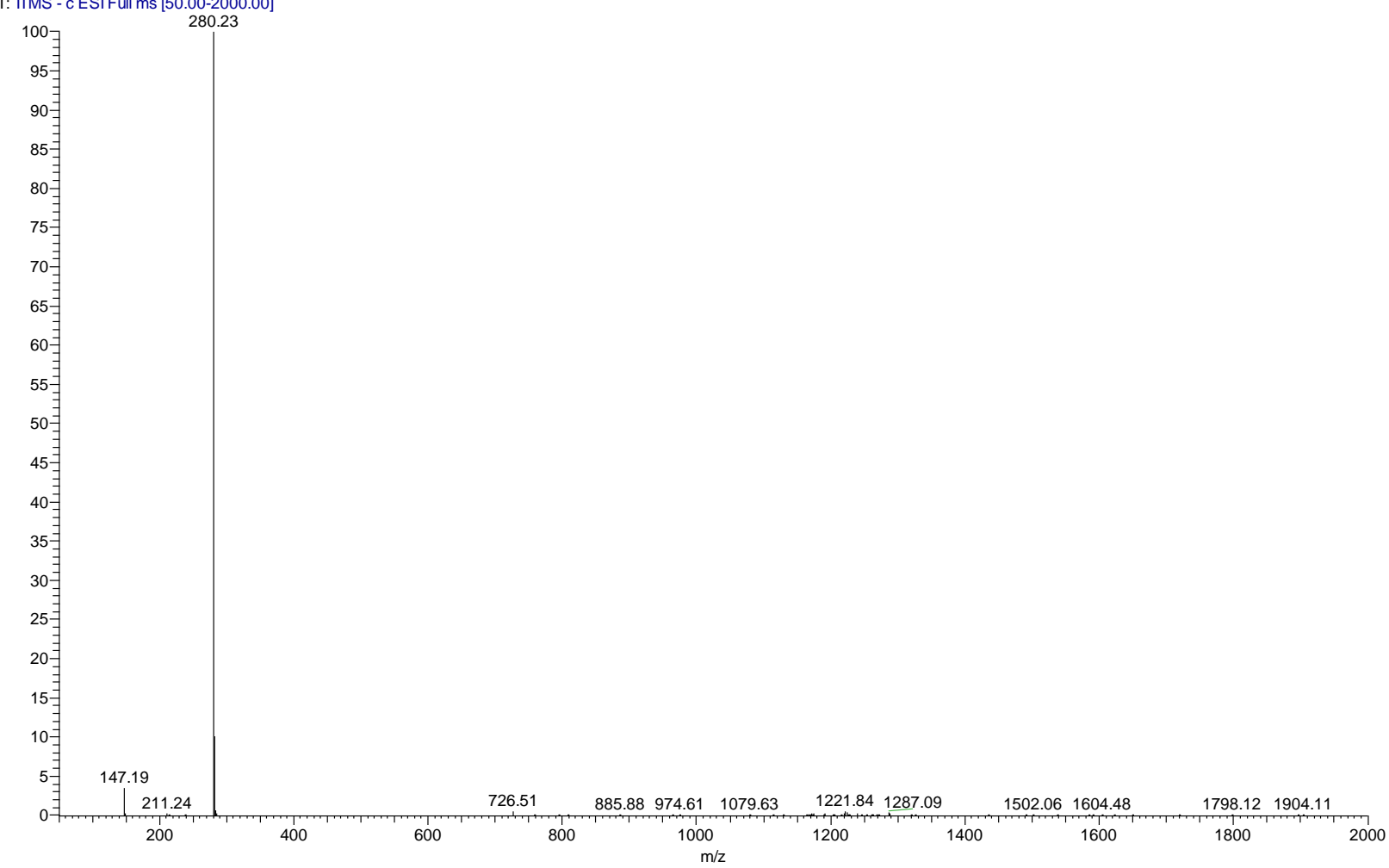




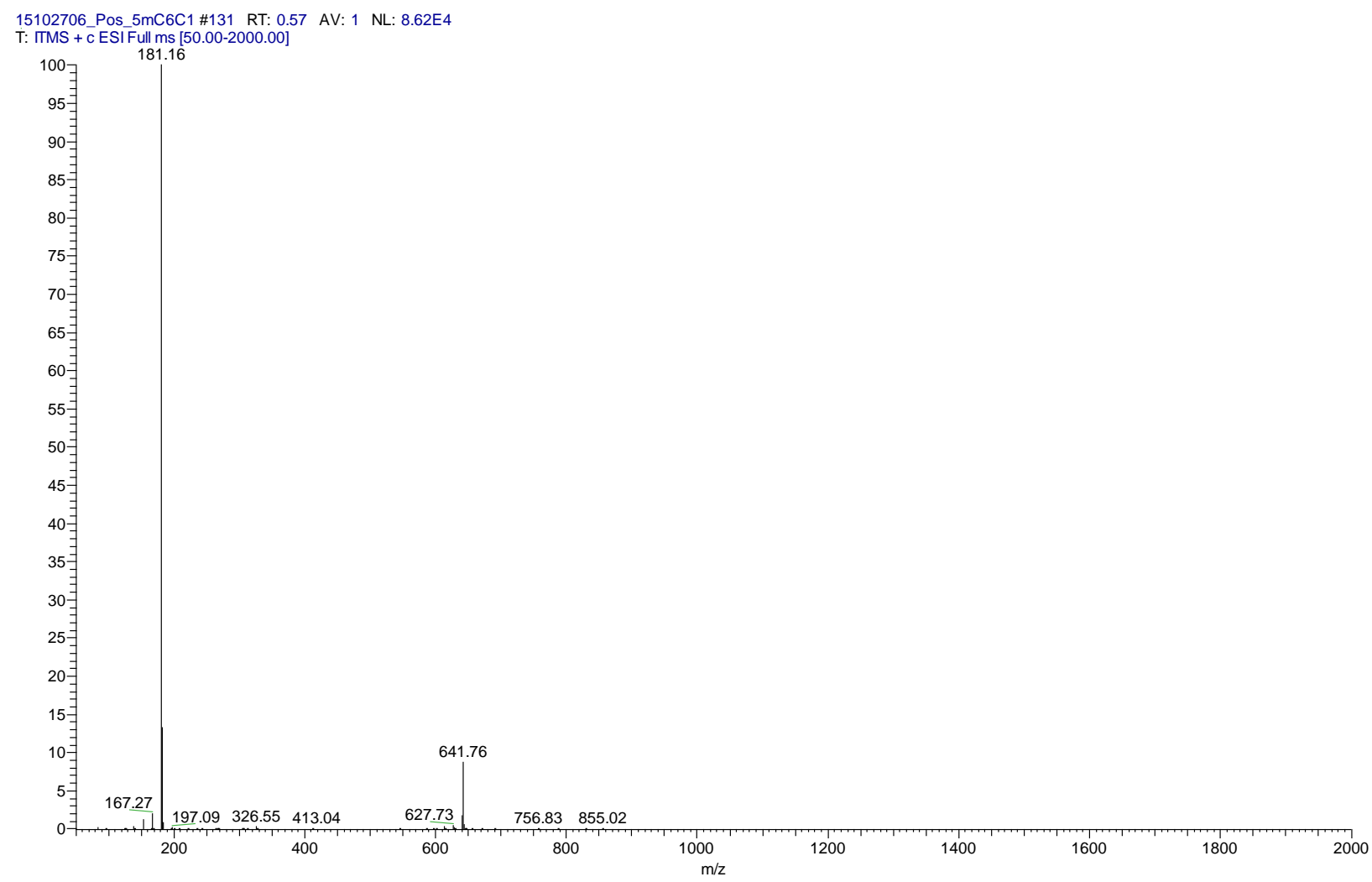

15102706_Neg 5mC6C1 \#117 RT: 1.47 AV: 1 NL: 1.49E4

T: TMS - c ESI Full ms [50.00-2000.00]

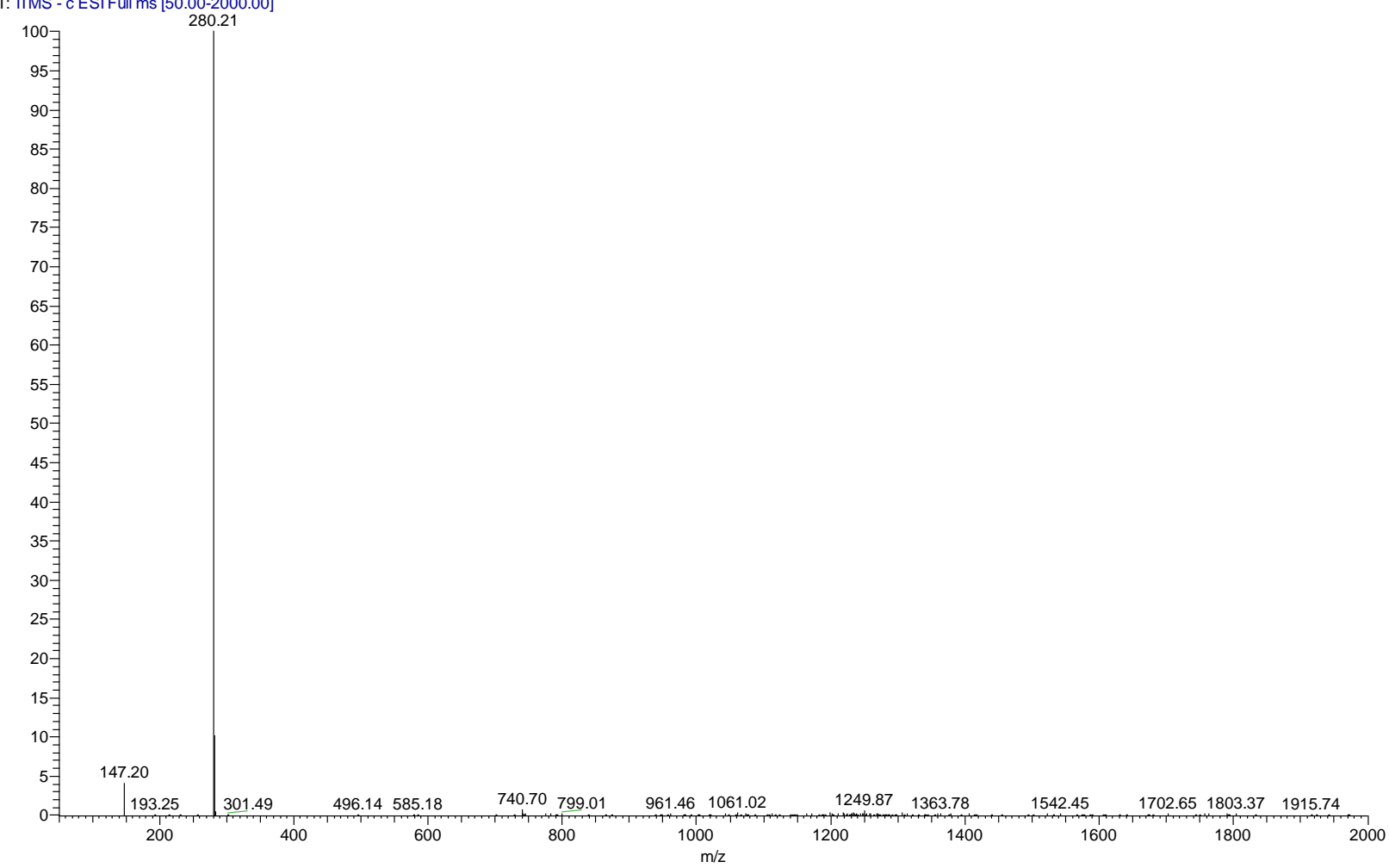




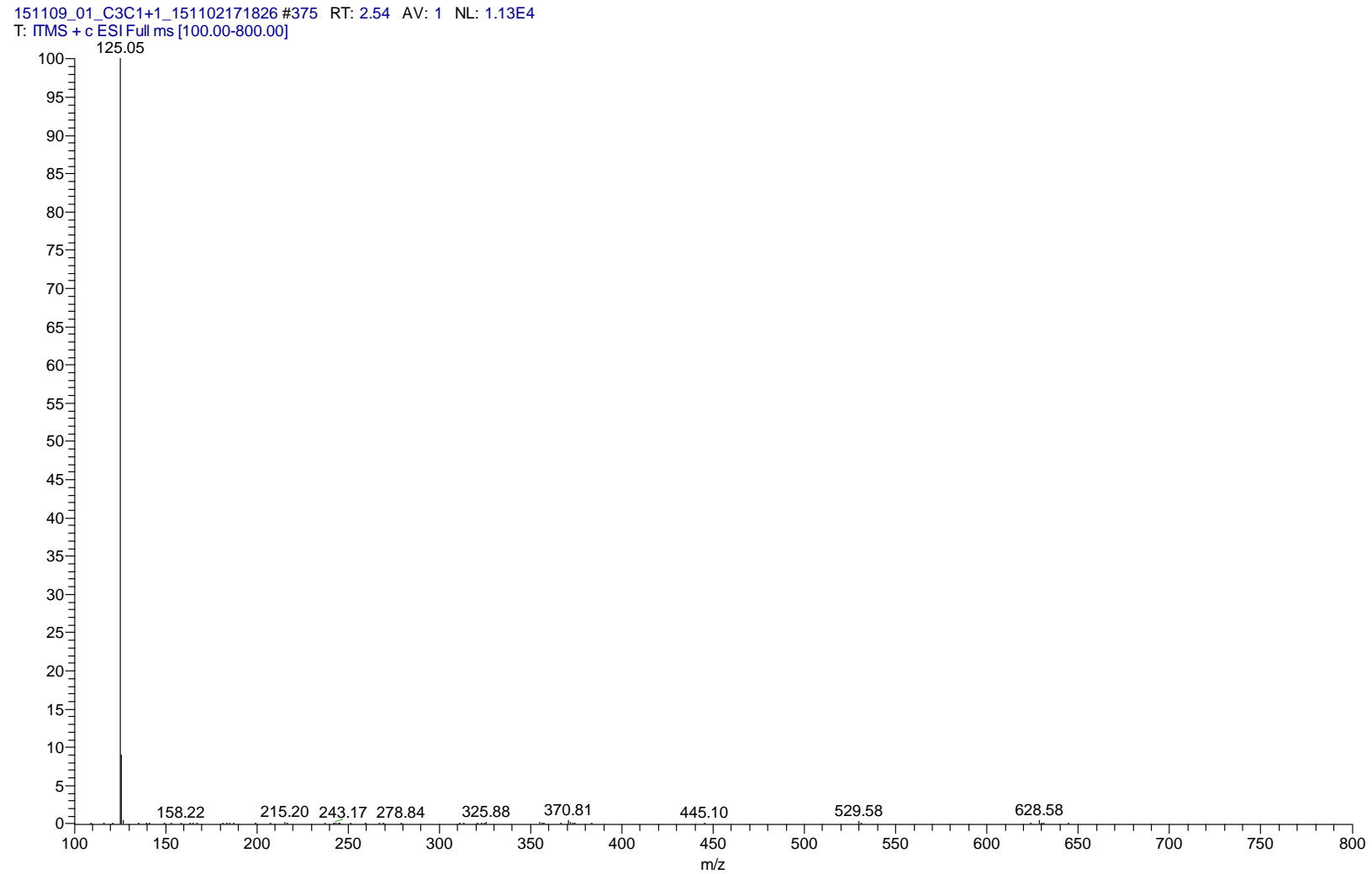




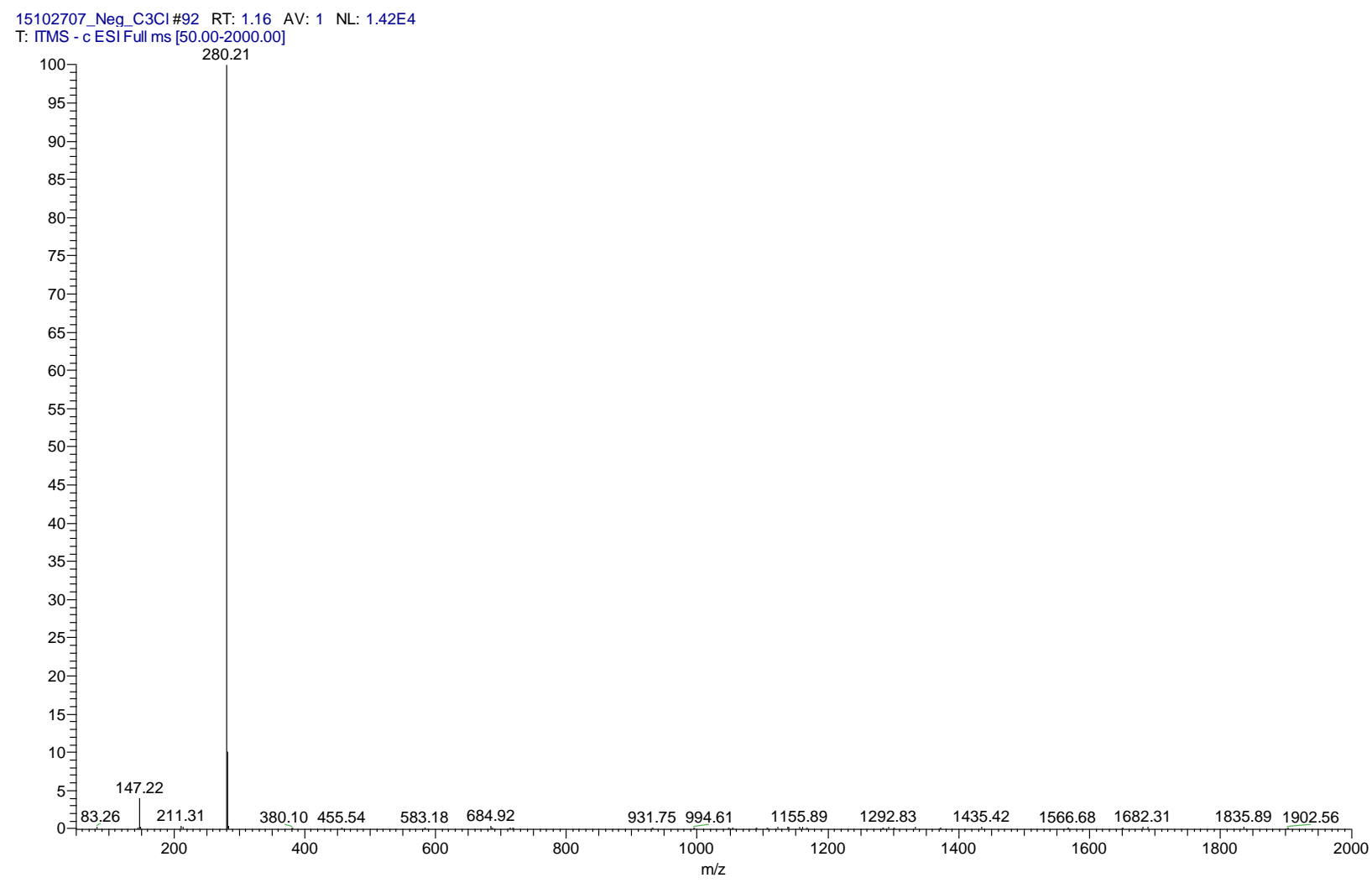

15110902 C4C1+1 151109092413 \#43 RT: 0.60 AV: 1 NL: 9.74E3 T: TMS + c ESI Full ms [100.00-2000.00]

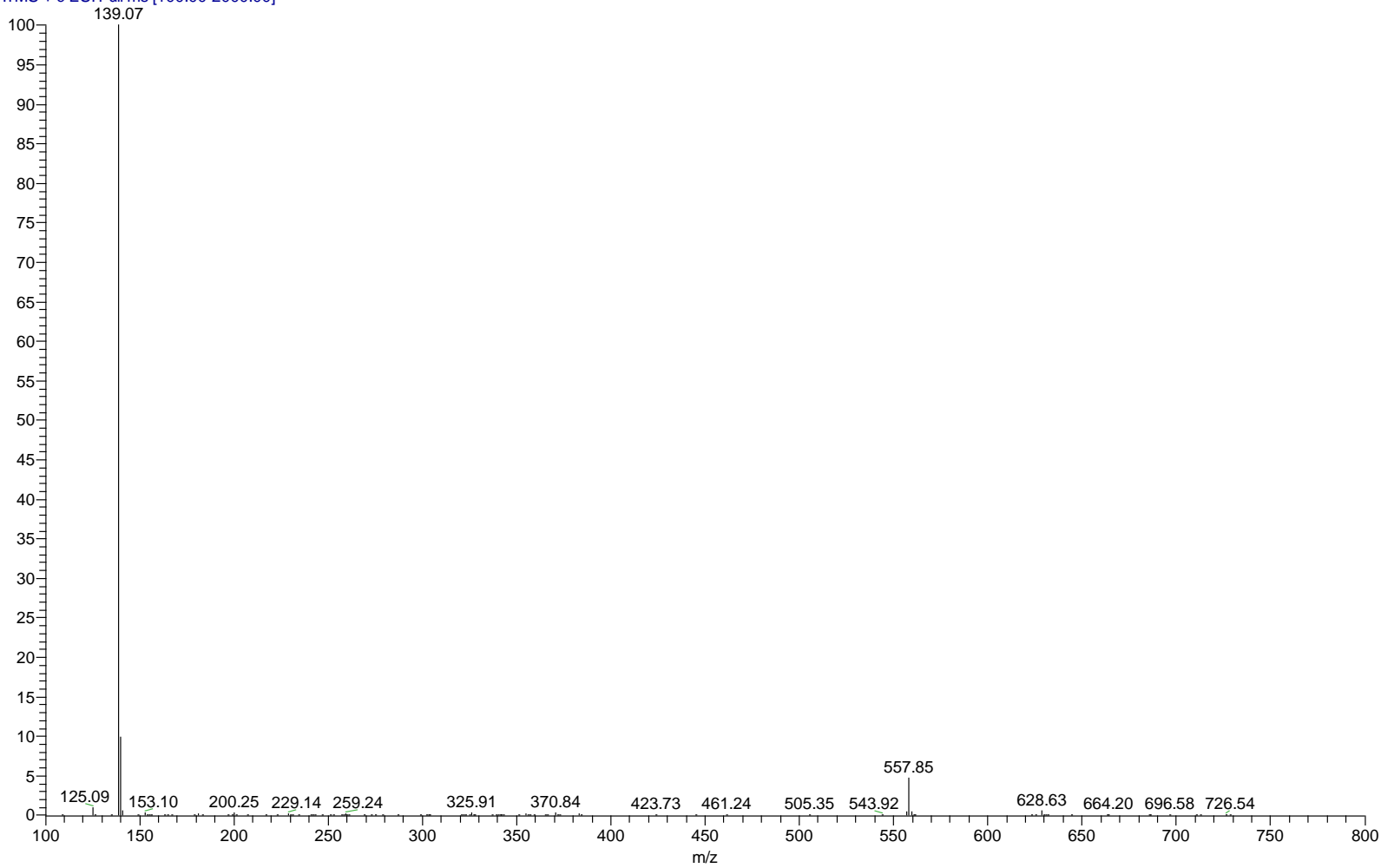



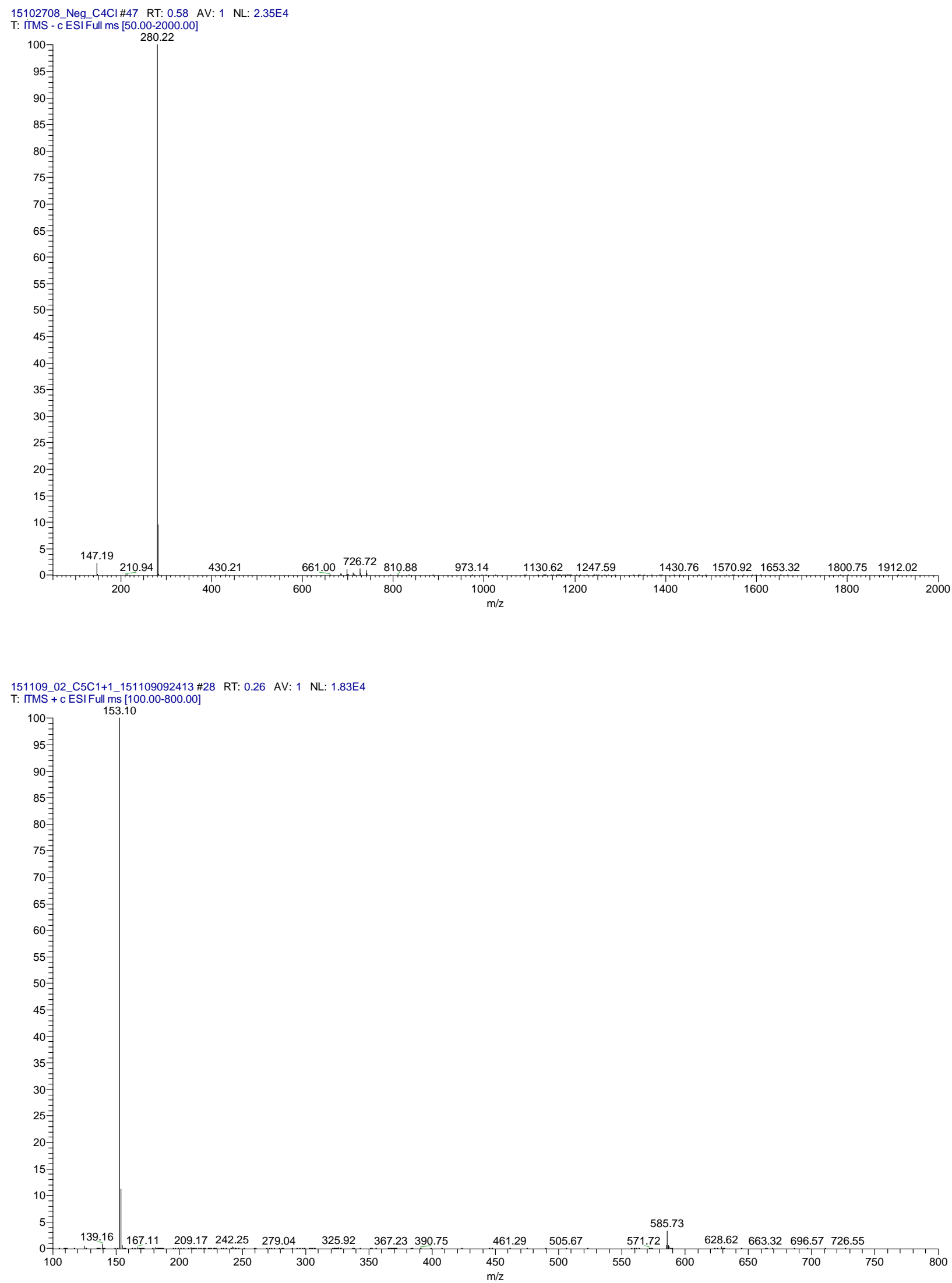

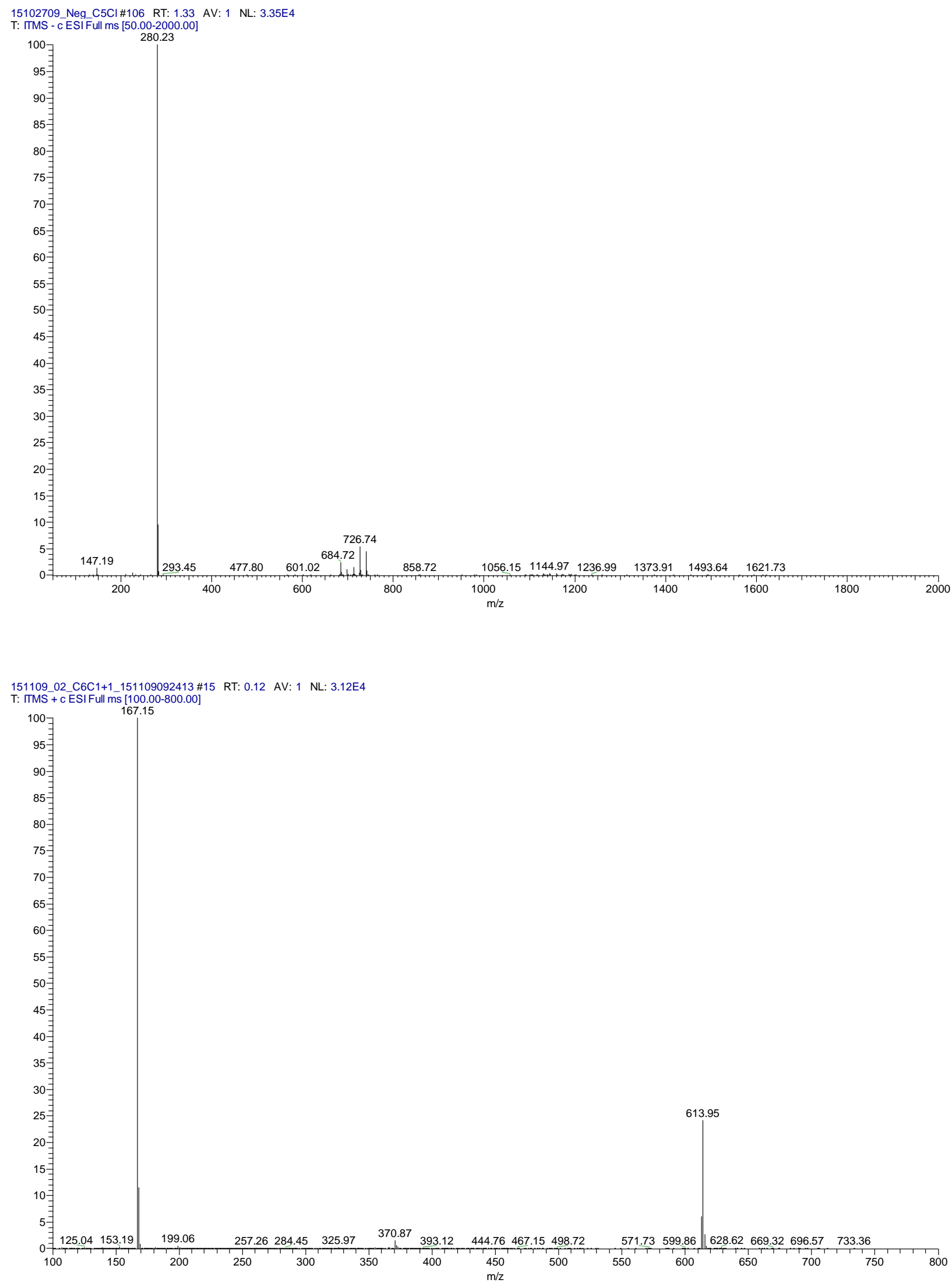

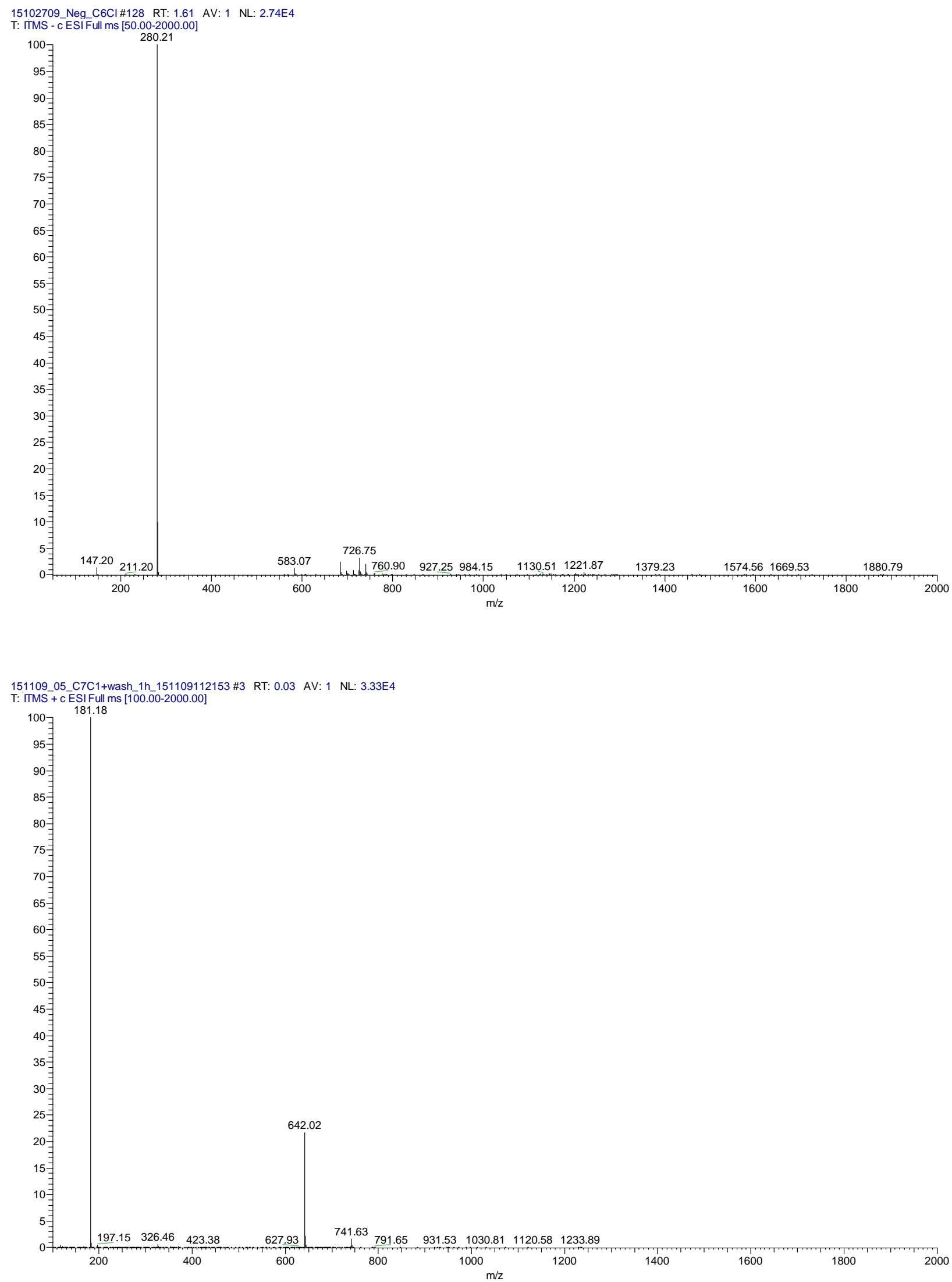


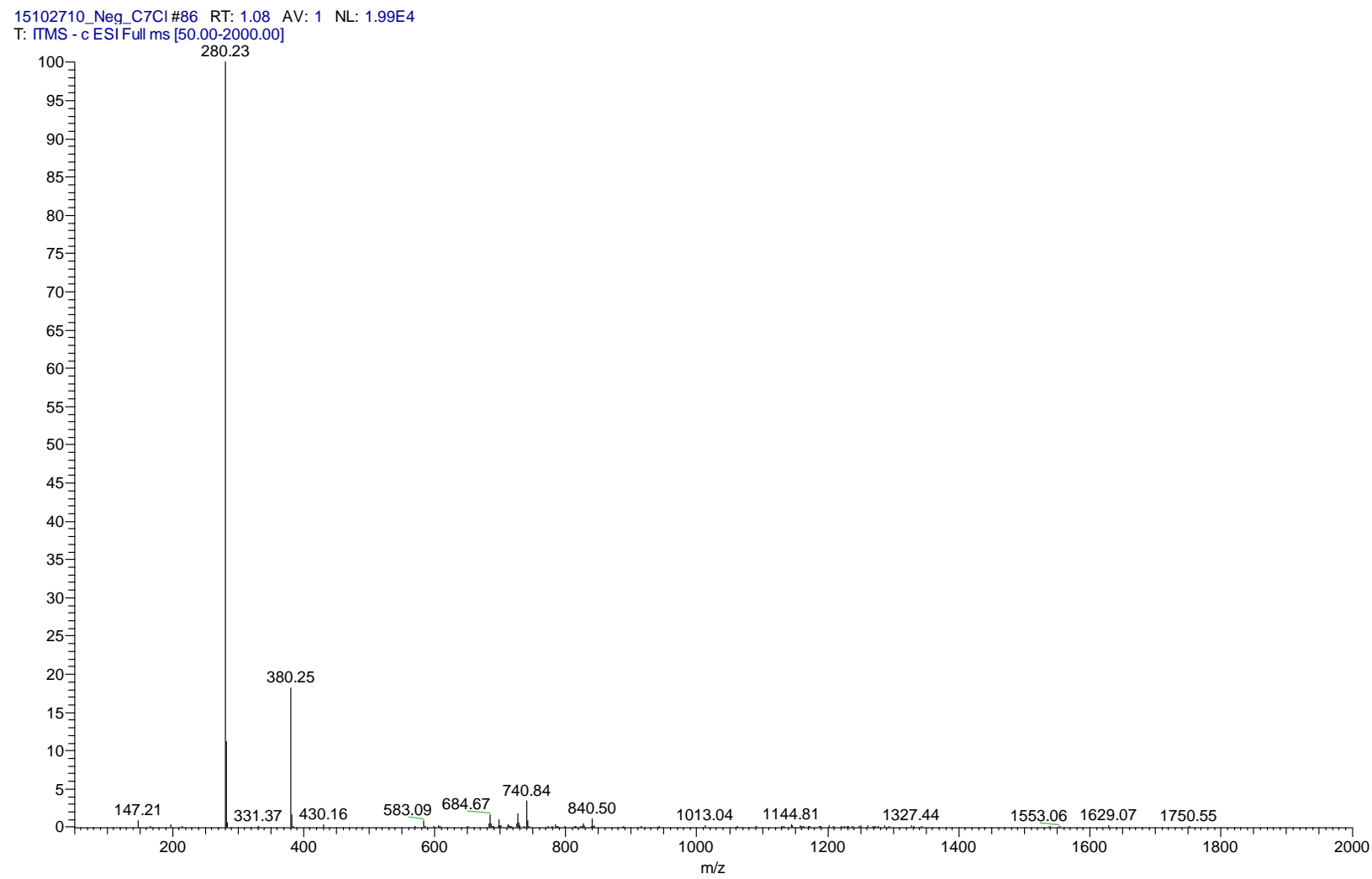




\section{6. $N M R$ Spectra of Branched Ionic Liquids $\left[(\mathrm{N}-2) \mathrm{mC}_{\mathrm{N}-1} \mathrm{C}_{1} \mathrm{im}\right]\left[\mathrm{NTf} \mathrm{f}_{2}\right]$ with $\mathrm{N}=3-7$.}<smiles></smiles>

\section{$\left[1 \mathrm{mC}_{2} \mathrm{C}_{1} \mathrm{im}\right]\left[\mathrm{NTf}_{2}\right]$}

1-(1-methylethyl)-3-methylimidazolium bis[(trifluoromethane)sulfonyl]amide

${ }^{1} \mathrm{H}$ NMR (400 MHz, Acetone- $\left.d_{6}\right): 9.06(\mathrm{~s}, 1 \mathrm{H}), 7.83(\mathrm{t}, J=1.83 \mathrm{~Hz}, 1 \mathrm{H}), 7.70(\mathrm{t}, J=1.83 \mathrm{~Hz}$, $1 \mathrm{H}), 4.81$ (sept, $J=6.87 \mathrm{~Hz}, 2 \mathrm{H}), 4.04(\mathrm{~s}, 3 \mathrm{H}), 1.6(\mathrm{~d}, J=6.87,6 \mathrm{H})$

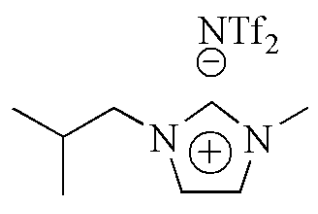

\section{$\left[2 \mathrm{mC}_{3} \mathrm{C}_{1} \mathrm{im}\right]\left[\mathrm{NTf}_{2}\right]$}

1-(2-methylpropyl)-3-methylimidazolium bis[(trifluoromethane)sulfonyl]amide

${ }^{1} \mathrm{H}$ NMR (400 MHz, Acetone- $\left.d_{6}\right): 9.03(\mathrm{~s}, 1 \mathrm{H}), 7.76-7.73(\mathrm{~m}, 2 \mathrm{H}), 4.19(\mathrm{~d}, J=7.33 \mathrm{~Hz}, 2 \mathrm{H})$, $4.07(\mathrm{~s}, 3 \mathrm{H}), 2.30-2.16(\mathrm{~m}, 1 \mathrm{H}), 0.95(\mathrm{~d}, J=6.41,6 \mathrm{H})$

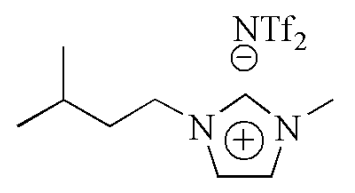

\section{$\left[3 \mathrm{mC}_{4} \mathrm{C}_{1} \mathrm{im}\right]\left[\mathrm{NTf}_{2}\right]$}

1-(3-methylbutyl)-3-methylimidazolium bis[(trifluoromethane)sulfonyl]amide

${ }^{1} \mathrm{H}$ NMR (400 MHz, Acetone- $\left.d_{6}\right): 9.06(\mathrm{~s}, 1 \mathrm{H}), 7.79(\mathrm{t}, J=1.83 \mathrm{~Hz}, 1 \mathrm{H}), 7.71(\mathrm{t}, J=1.83 \mathrm{~Hz}$, $1 \mathrm{H}), 4.39$ (t, J=7.79 Hz, 2H), 4.05 (s, 3H), 1.85 (q, J=7.79, 2H), 1.70-1.57 (m, 1H), 0.95 (d, J $=6.41 \mathrm{~Hz}, 6 \mathrm{H})$

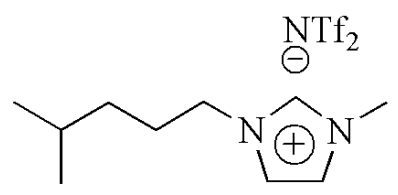

\section{$\left[4 \mathrm{mC}_{5} \mathrm{C}_{1} \mathrm{im}\right]\left[\mathrm{NTf}_{2}\right]$}

1-(4-methylpentyl)-3-methylimidazolium bis[(trifluoromethane)sulfonyl]amide ${ }^{1} \mathrm{H}$ NMR (400 MHz, Acetone- $\left.d_{6}\right): 9.01(\mathrm{~s}, 1 \mathrm{H}), 7.76(\mathrm{t}, J=1.83 \mathrm{~Hz}, 1 \mathrm{H}), 7.69$ (t, $J=1.83 \mathrm{~Hz}$, $1 \mathrm{H}), 4.33(\mathrm{t}, J=7.33 \mathrm{~Hz}, 2 \mathrm{H}), 4.04(\mathrm{~s}, 3 \mathrm{H}), 1.98-1.91(\mathrm{~m}, 2 \mathrm{H}), 1.64-1.51(\mathrm{~m}, 1 \mathrm{H}), 1.26-1.1 .21(\mathrm{~m}$, $2 \mathrm{H}), 0.86(\mathrm{~d}, J=6.87 \mathrm{~Hz}, 6 \mathrm{H})$ 


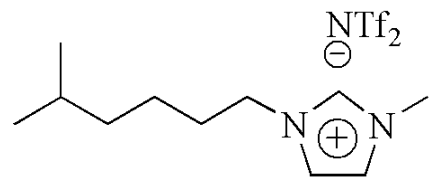

\section{$\left[5 \mathrm{mC}_{6} \mathrm{C}_{1} \mathrm{im}\right]\left[\mathrm{NTf}_{2}\right]$}

1-(5-methylhexyl)-3-methylimidazolium bis[(trifluoromethane)sulfonyl]amide

${ }^{1} \mathrm{H}$ NMR $\left(400 \mathrm{MHz}\right.$, Acetone- $\left.d_{6}\right): 9.03(\mathrm{~s}, 1 \mathrm{H}), 7.77(\mathrm{t}, J=1.83 \mathrm{~Hz}, 1 \mathrm{H}), 7.70(\mathrm{t}, J=1.83 \mathrm{~Hz}$, $1 \mathrm{H}), 4.36(\mathrm{t}, J=7.50 \mathrm{~Hz}, 2 \mathrm{H}), 4.05(\mathrm{~s}, 3 \mathrm{H}), 1.93$ (quin, $J=7.33,2 \mathrm{H}), 1.58-1.45(\mathrm{~m}, 1 \mathrm{H}), 1.40-$ 1.1.32 (m, 2H), $1.25-1.19(\mathrm{~m}, 2 \mathrm{H}), 0.84(\mathrm{~d}, J=6.87 \mathrm{~Hz}, 6 \mathrm{H})$

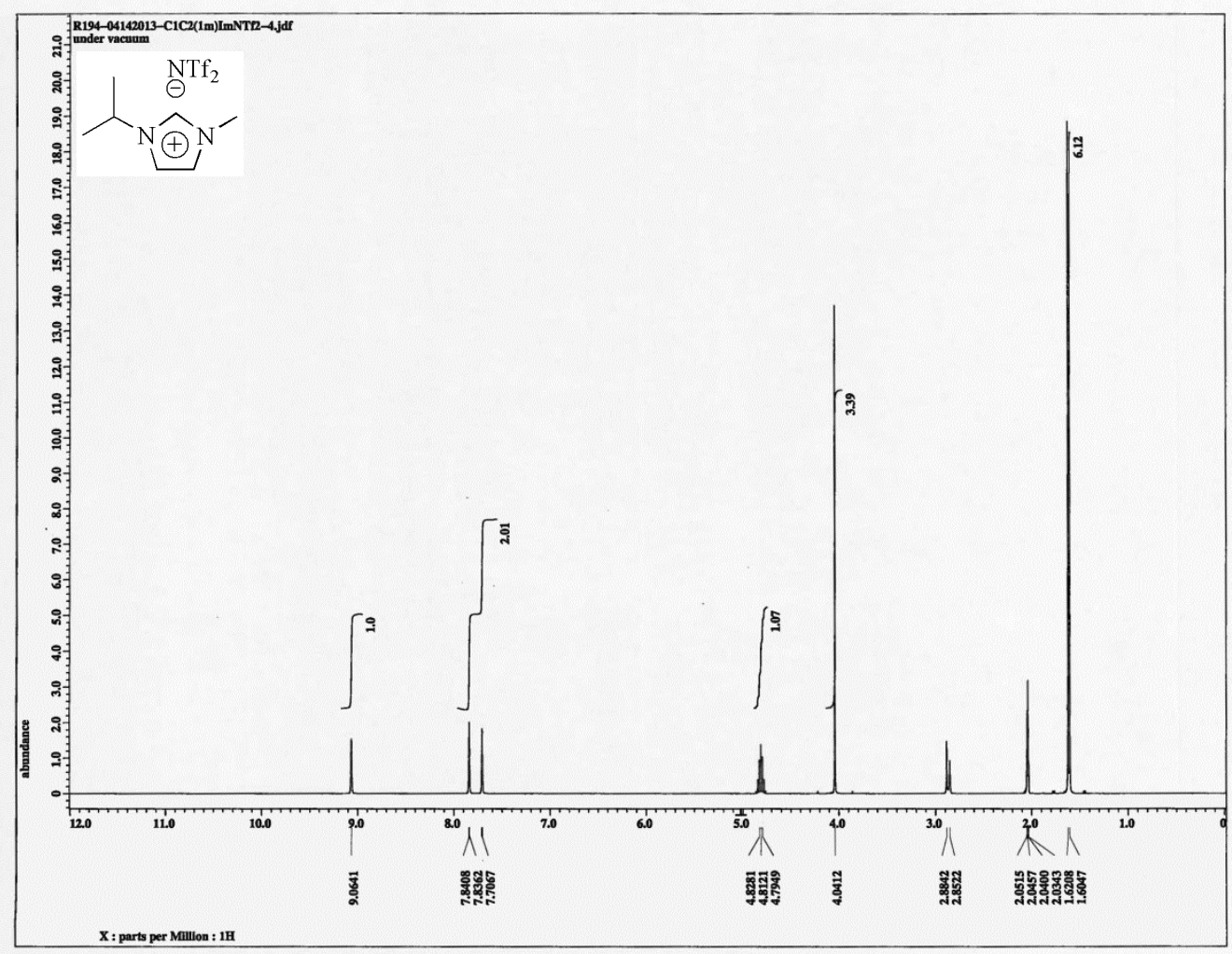




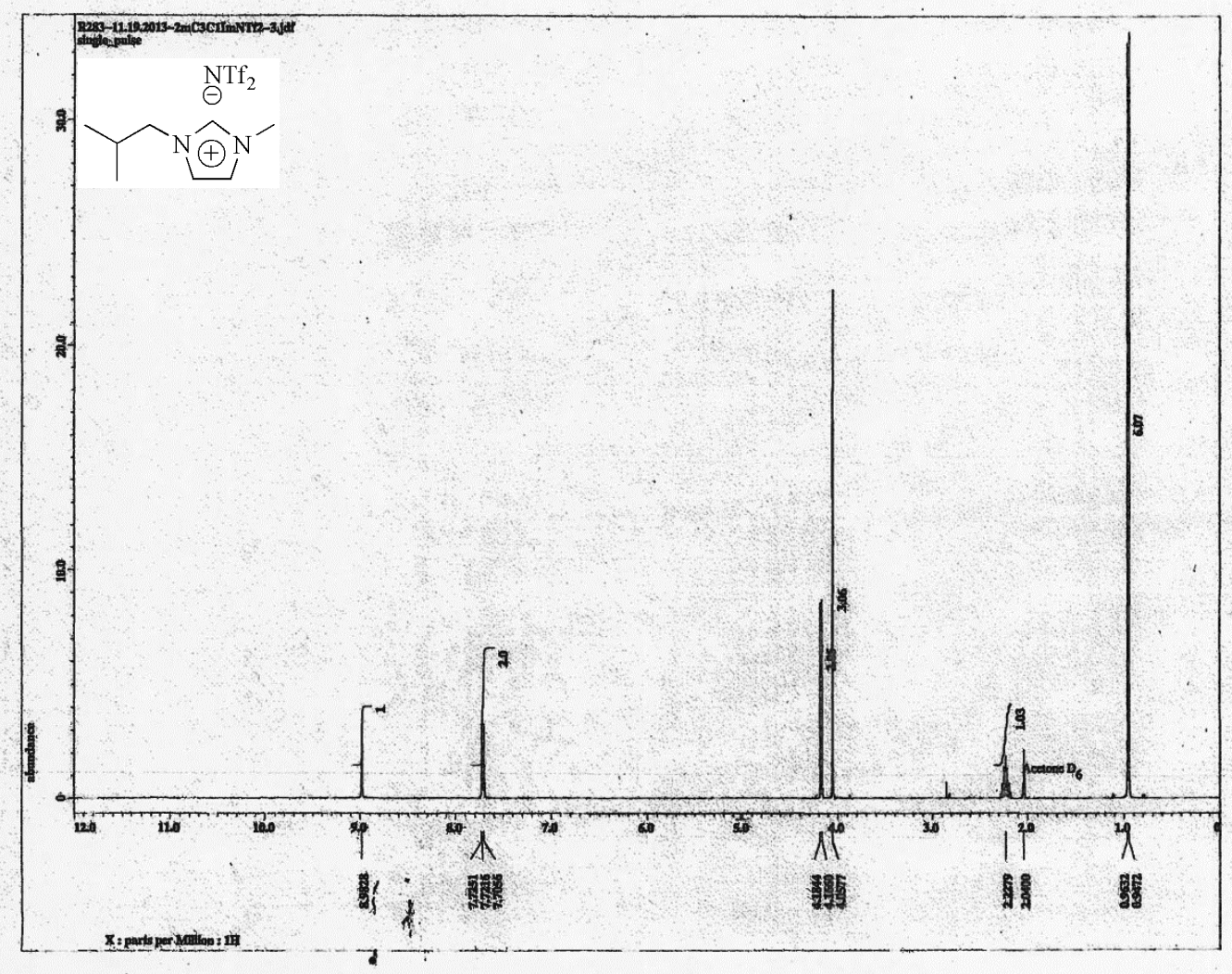




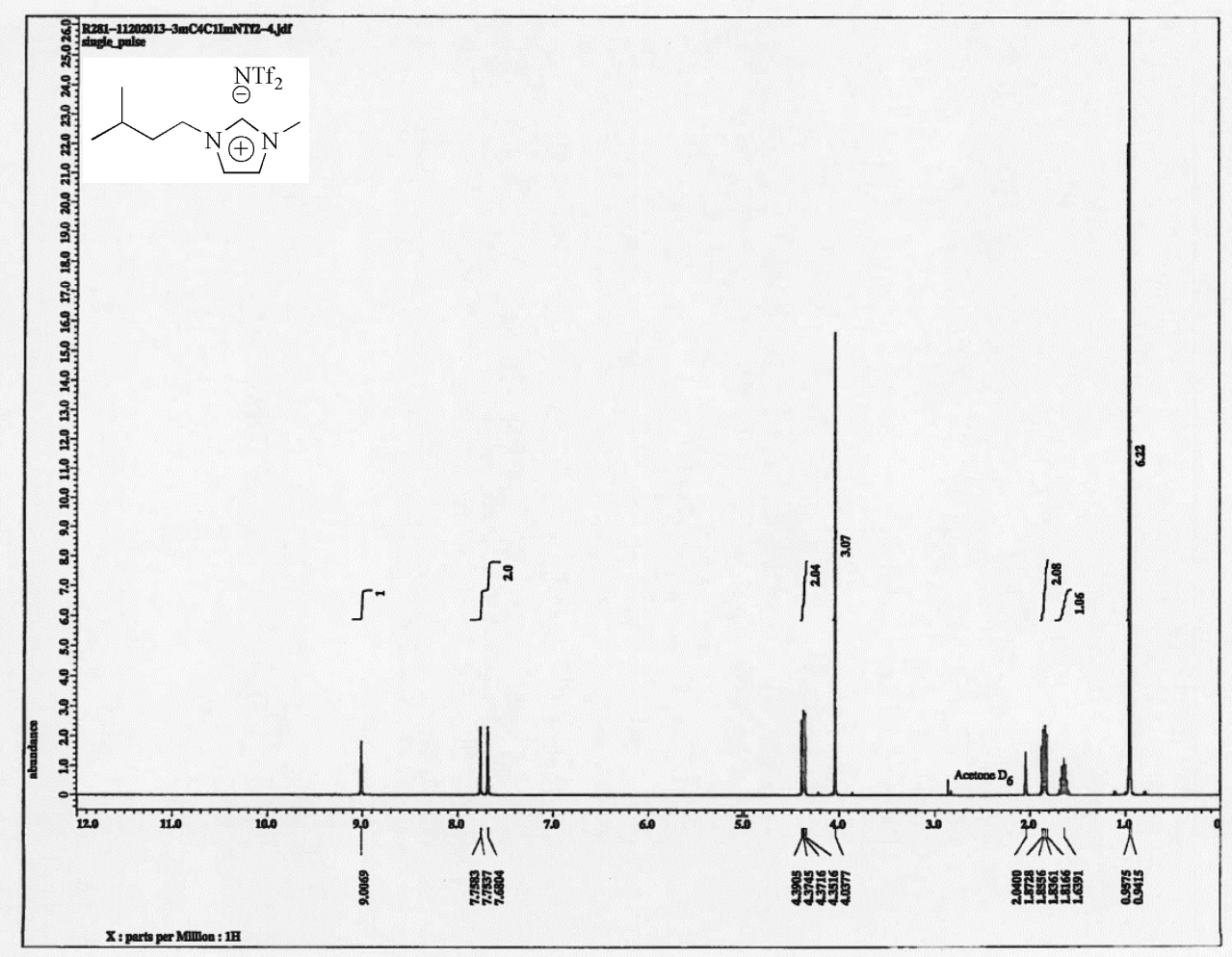




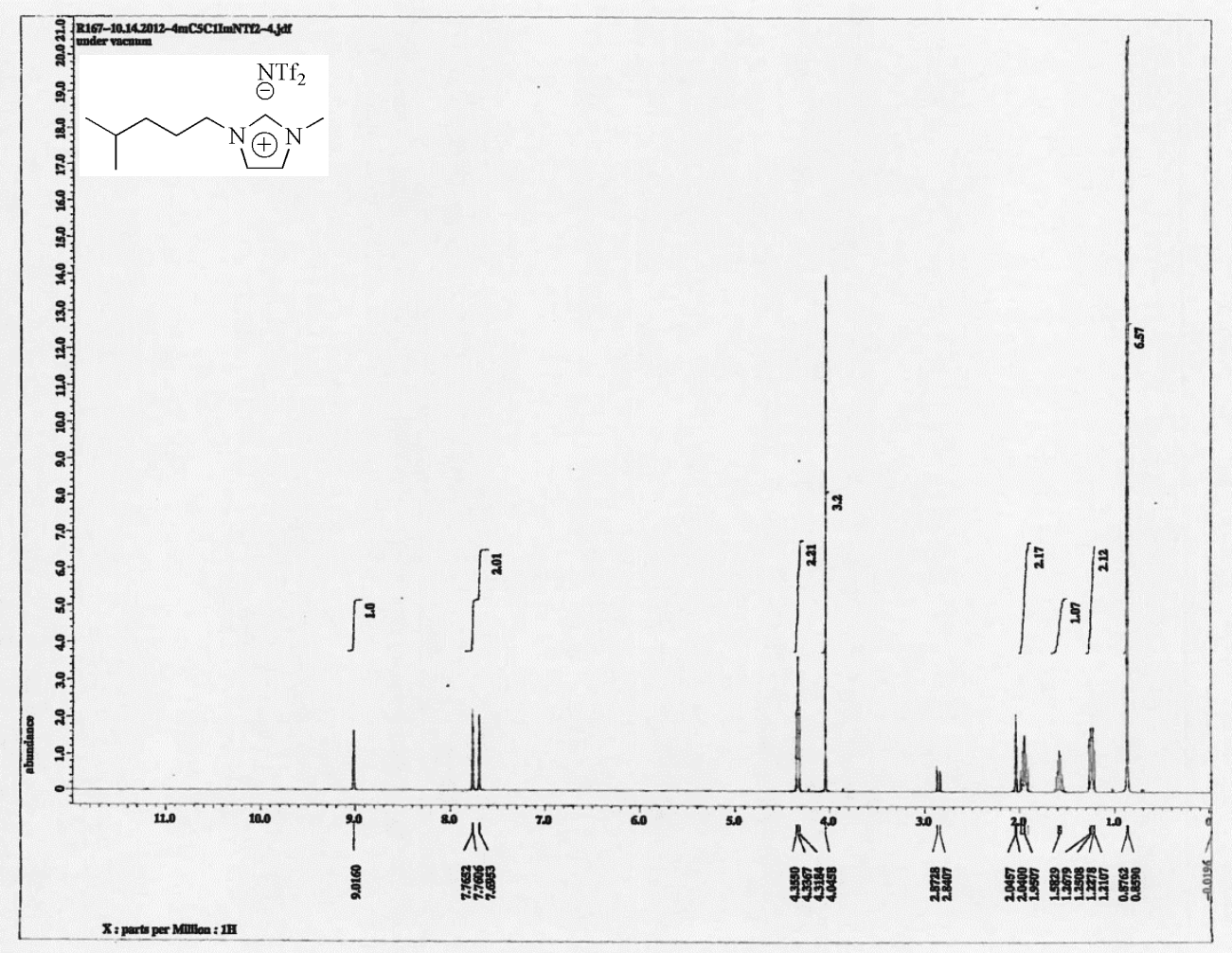




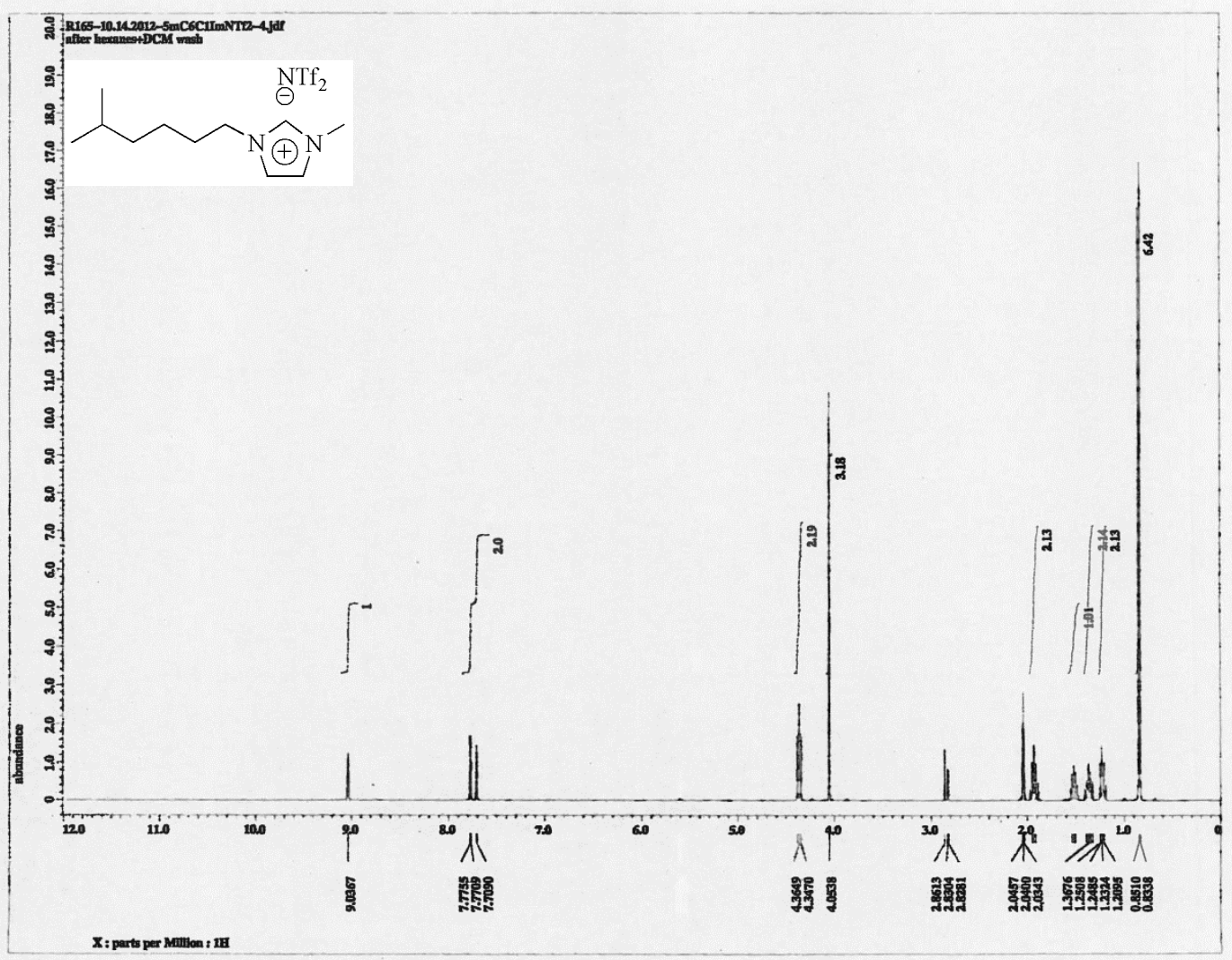




\section{Calibration of Density Meter and Viscosity-Induced Error Correction}

The Paar DMA 60/602 vibrating tube density meter was calibrated by determining the constant $k$ in the equation

$$
\rho_{1}-\rho_{2}=k\left(T_{1}^{2}-T_{2}^{2}\right)
$$

where $\rho_{1}$ and $\rho_{2}$ are the densities of two different liquids or gases, and $T_{1}$ and $T_{2}$ are the corresponding vibrational periods obtained in the measurement. The value of the calibration $k$ was obtained at different temperatures. For the current measurements, the DMA 60/602 was calibrated using air and tetrachloroethylene (Sigma-Aldrich > 99\%). Certified densities of tetrachloroethylene were obtained from H\&D Fitzgerald Ltd. The densities of the ILs and the Lube Oil standards were determined from eq S1 using tetrachloroethylene as the reference standard.

Because of the high viscosities of the ILs, the densities must be corrected for viscosityinduced errors. The viscosity-induced error due to shear forces leads to higher values of the density than the actual ones. ${ }^{4}$ In the current study, a calibration procedure reported by Sanmamed et al ${ }^{5-6}$ was used to determine the viscosity induced error $\Delta \rho(\eta)$. In this procedure the viscosityinduced error as function of temperature was obtained for a density standard using the equation

$$
\Delta \rho(\eta)=\rho^{\text {meas }}-\rho^{\text {cert }}
$$

where $\rho^{\text {meas }}$ and $\rho^{\text {cert }}$ denote the measured and certified densities of the standard, respectively. To cover the viscosity range of the ILs in this study, three density standards obtained from H\&D Fitzgerald, Ltd, Lube Oil Largo 32, Lube Oil A90, and Lube Oil Largo 100, were used. The results from these measurements are summarized in Table S4.

Table S4. Densities $\rho^{\text {meas }}$ and $\rho^{\text {cert }}$ for Standards as a Function of Temperature at $0.1 \mathrm{MPa}^{\mathrm{a}}{ }^{\mathrm{a}}$

\begin{tabular}{|c|c|c|c|c|c|c|}
\hline \multirow{2}{*}{$\mathrm{T}(\mathrm{K})$} & \multicolumn{5}{|c|}{$\rho\left(\mathrm{g} \mathrm{cm}^{-3}\right)$} \\
\cline { 2 - 7 } & \multicolumn{2}{|c|}{ Lube Oil Largo 32 } & \multicolumn{2}{|c|}{ Lube Oil A90 } & \multicolumn{2}{c|}{ Lube oil Largo 100 } \\
\hline & Measured & Certified & Measured & Certified & Measured & Certified \\
\hline 283.15 & 0.87358 & 0.87305 & 0.89371 & & 0.88593 & 0.88528 \\
\hline 288.15 & 0.87019 & 0.86987 & 0.89048 & 0.88977 & 0.88270 & 0.88217 \\
\hline 293.15 & 0.86716 & 0.86669 & 0.88756 & 0.88668 & 0.87975 & 0.87906 \\
\hline 298.15 & 0.86384 & 0.86352 & 0.88442 & 0.88360 & 0.87661 & 0.87597 \\
\hline 303.15 & 0.86054 & 0.86035 & 0.88131 & 0.88060 & 0.87350 & 0.87287 \\
\hline 308.15 & 0.85721 & 0.85718 & 0.87808 & 0.87745 & 0.87032 & 0.86979 \\
\hline 313.15 & 0.85371 & 0.85402 & 0.87481 & 0.87438 & 0.86711 & 0.86671 \\
\hline
\end{tabular}

${ }^{\mathrm{a}}$ Standards and certified densities obtained from H\&D Fitzgerald, Ltd. 
The viscosity-induced correction $\Delta \rho(\eta)$ is assumed to be only a function of viscosity $\eta$. The combined data Table S4 are fit by the empirical function

$$
\Delta \rho(\eta)=\frac{\eta^{2}}{q_{1}+q_{2} \eta+q_{3} \eta^{2}}
$$

where $q_{1}, q_{2}$, and $q_{3}$ are fit parameters. The viscosities of the density standards used for determining the viscosity-induced error were provided by H\&D Fitzgerald, Ltd. However, the viscosities were given for a limited set of temperatures. In order to obtain values of the viscosities over a wider range of temperature, the viscosities provided by H\&D Fitzgerald, Ltd. were fit by the empirical function

$$
\eta=\exp C_{0}+C_{1}\left(\frac{1}{T}\right)+C_{2}\left(\frac{1}{T}\right)^{2}
$$

with the values of the fit parameter $C_{0}, C_{1}$, and $C_{2}$ listed in Table S5. Viscosities (Table S6) were then calculated at temperatures for which values of $\Delta \rho(\eta)$ were obtained.

Table S5. Viscosity Fit Parameters for Density Standards. ${ }^{\text {a }}$

\begin{tabular}{|c|c|c|c|}
\hline Density Standard & $C_{0}$ & $C_{1}$ & $C_{2}$ \\
\hline Lube Oil Largo 32 & $8.0 \pm 0.4$ & $-(6.9 \pm 0.2) \times 10^{3}$ & $(1.73 \pm 0.03) \times 10^{6}$ \\
\hline Lube Oil A90 & $10.4 \pm 0.2$ & $-(8.90 \pm 0.14) \times 10^{3}$ & $(2.27 \pm 0.02) \times 10^{6}$ \\
\hline Lube Oil Largo 100 & $13 \pm 2$ & $-(10.2 \pm 1.3) \times 10^{3}$ & $(2.4 \pm 0.2) \times 10^{6}$ \\
\hline
\end{tabular}

${ }^{\mathrm{a}} \mathrm{See}$ eq $\mathrm{S} 4$ for definition of fit parameters.

Table S6. Viscosity of Lube Oils as a Function of Temperature ${ }^{a}$

\begin{tabular}{|c|c|c|c|}
\hline \multirow{2}{*}{$\mathrm{T}(\mathrm{K})$} & \multicolumn{3}{|c|}{$\eta(\mathrm{mPa}-\mathrm{s})$} \\
\cline { 2 - 4 } & $\begin{array}{c}\text { Lube Oil } \\
\text { Largo 32 }\end{array}$ & $\begin{array}{c}\text { Lube Oil } \\
\text { A90 }\end{array}$ & $\begin{array}{c}\text { Lube Oil } \\
\text { Largo 100 }\end{array}$ \\
\hline 283.15 & 155.83 & & \\
\hline 288.15 & 113.59 & 866.00 & 478.86 \\
\hline 293.15 & 84.80 & 582.79 & 335.78 \\
\hline 298.15 & 64.68 & 403.75 & 241.54 \\
\hline 303.15 & 50.29 & 287.20 & 177.83 \\
\hline 308.15 & 32.00 & 155.84 & 133.70 \\
\hline 313.15 & 21.57 & 91.60 & 102.50 \\
\hline
\end{tabular}

\footnotetext{
${ }^{a}$ Viscosities calculated using eq S4 and fit parameters in Table S5.
} 
Figure S1 shows a plot of the viscosity-induced correction $\Delta \rho(\eta)$ as a function of viscosity. (Note the units of $\Delta \rho(\eta)$ in Figure $\mathrm{S} 1$ are $\mathrm{kg} \mathrm{m}^{-3}$.) A nonlinear least-squares fit of eq S3 to the points in this plot yielded fit parameters $q_{1}=11997.87589, q_{2}=6.83615$, and $q_{3}=1.28165$. Using the empirical function eq S3 and the values of the viscosities of the ILs given Table 6 of the article, estimates of the viscosity-induced error for each of the ILs at temperatures of the density measurements were made.

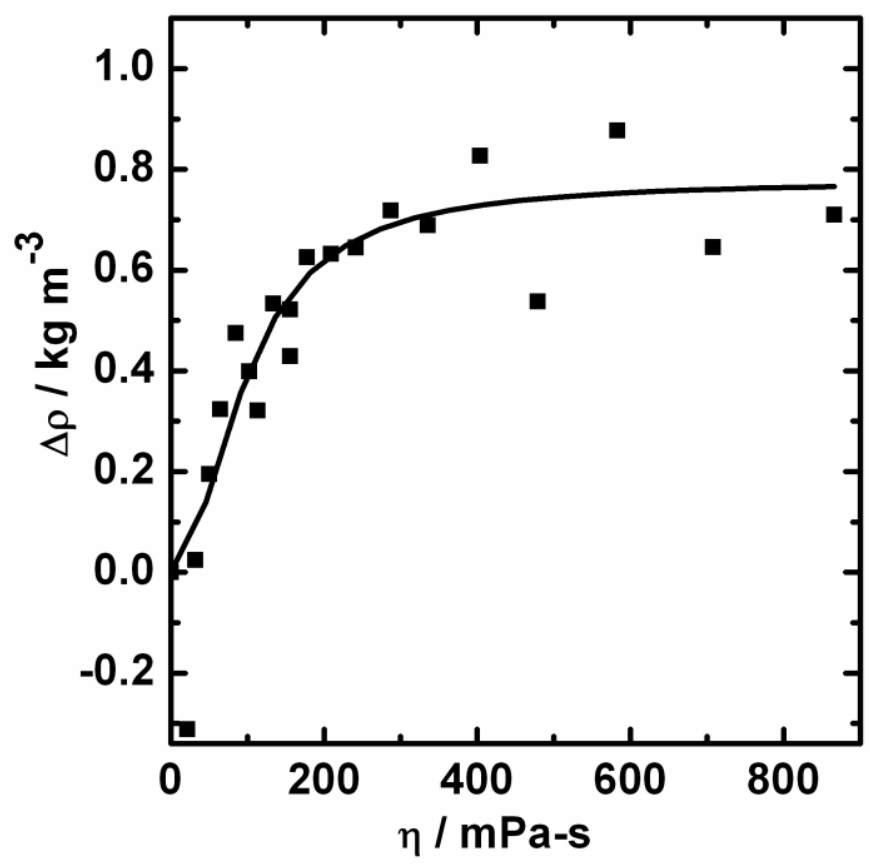

Figure S1. Viscosity-induced errors $\Delta \rho$ (points) as function of viscosity, $\eta$, for the density standards Oil Largo 32, Lube Oil A90, and Lube Oil Largo 100. Values calculated from the data in Tables S4 and S6. The solid line through the points is a fit of eq S3 to the data with $q_{1}=$ $11997.87589, q_{2}=6.83615$, and $q_{3}=1.28165$.

The viscosity-induced error $\Delta \rho(\eta)$ for each of the ILs were calculated at the various temperatures the density measured and converted from units of $\mathrm{kg}-\mathrm{m}^{-3}$ to $\mathrm{g}-\mathrm{cm}^{-3}$. The measured densities were corrected for viscosity-induced errors using the equation

$$
\rho^{\text {corr }}=\rho^{\text {meas }}-\Delta \rho(\eta)
$$

Tables S7 and S8 list the values of the measured densities and the densities corrected for viscosity-induced error, respectively, for the linear and branched ILs. 
Table S7. Densities, as Measured and Corrected for Viscosity-Induced Errors, for Linear ILs as a Function of Temperature at $0.1 \mathrm{MPa}$.

\begin{tabular}{|c|c|c|c|c|c|c|c|c|c|c|}
\hline & \multicolumn{10}{|c|}{$\rho\left(\mathrm{g}-\mathrm{cm}^{-3}\right)$} \\
\cline { 2 - 12 } $\mathrm{T}(\mathrm{K})$ & \multicolumn{2}{|c|}{$\mathrm{C}_{3} \mathrm{C}_{1}$} & \multicolumn{2}{|c|}{$\mathrm{C}_{4} \mathrm{C}_{1}$} & \multicolumn{2}{|c|}{$\mathrm{C}_{5} \mathrm{C}_{1}$} & \multicolumn{2}{|c|}{$\mathrm{C}_{6} \mathrm{C}_{1}$} & \multicolumn{3}{|c|}{$\mathrm{C}_{7} \mathrm{C}_{1}$} \\
\hline & Uncorr & Corr & Uncorr & Corr & Uncorr & Corr & Uncorr & Corr & Uncorr & Corr \\
\hline 283.15 & 1.4905 & 1.4902 & 1.4516 & 1.4512 & 1.4179 & 1.4175 & 1.3866 & 1.3861 & 1.3589 & 1.3584 \\
\hline 288.15 & 1.4854 & 1.4852 & 1.4468 & 1.4465 & 1.4132 & 1.4129 & 1.3819 & 1.3815 & 1.3546 & 1.3541 \\
\hline 293.15 & 1.4807 & 1.4806 & 1.4422 & 1.4419 & 1.4087 & 1.4084 & 1.3775 & 1.3772 & 1.3502 & 1.3498 \\
\hline 298.15 & 1.4757 & 1.4756 & 1.4370 & 1.4369 & 1.4039 & 1.4036 & 1.3730 & 1.3727 & 1.3457 & 1.3454 \\
\hline 303.15 & 1.4709 & 1.4708 & 1.4322 & 1.4321 & 1.3992 & 1.3990 & 1.3686 & 1.3683 & 1.3412 & 1.3410 \\
\hline 308.15 & 1.4658 & 1.4658 & 1.4272 & 1.4271 & 1.3941 & 1.3939 & 1.3638 & 1.3636 & 1.3366 & 1.3364 \\
\hline 313.15 & 1.4606 & 1.4606 & 1.4227 & 1.4226 & 1.3893 & 1.3893 & 1.3590 & 1.3588 & 1.3318 & 1.3316 \\
\hline
\end{tabular}

Table S8. Densities, as Measured and Corrected for Viscosity-Induced Errors, for Branched ILs as a Function of Temperature at $0.1 \mathrm{MPa}$.

\begin{tabular}{|c|c|c|c|c|c|c|c|c|c|c|}
\hline \multirow{2}{*}{$\mathrm{T}(\mathrm{K})$} & \multicolumn{10}{|c|}{$\rho\left({\left.\mathrm{g}-\mathrm{cm}^{-3}\right)}^{-3}\right.$} \\
\cline { 2 - 12 } & \multicolumn{1}{|c|}{$1 \mathrm{mC}_{2} \mathrm{C}_{1}$} & \multicolumn{2}{|c|}{$2 \mathrm{mC}_{3} \mathrm{C}_{1}$} & \multicolumn{2}{|c|}{$4 \mathrm{mC}_{5} \mathrm{C}_{1}$} & \multicolumn{2}{|c|}{$5 \mathrm{mC}_{6} \mathrm{C}_{1}$} & \multicolumn{2}{|c|}{$6 \mathrm{mC}_{7} \mathrm{C}_{1}$} \\
\hline & Uncorr & Corr & Uncorr & Corr & Uncorr & Corr & Uncorr & Corr & Uncorr & Corr \\
\hline 283.15 & 1.4922 & 1.4922 & 1.4503 & 1.4503 & 1.4175 & 1.4175 & 1.3859 & 1.3859 & 1.3575 & 1.3575 \\
\hline 288.15 & 1.4872 & 1.4872 & 1.4456 & 1.4456 & 1.4127 & 1.4127 & 1.3813 & 1.3813 & 1.3530 & 1.3530 \\
\hline 293.15 & 1.4825 & 1.4825 & 1.4411 & 1.4411 & 1.4081 & 1.4081 & 1.3770 & 1.3770 & 1.3487 & 1.3487 \\
\hline 298.15 & 1.4776 & 1.4776 & 1.4363 & 1.4363 & 1.4033 & 1.4033 & 1.3724 & 1.3724 & 1.3442 & 1.3442 \\
\hline 303.15 & 1.4728 & 1.4728 & 1.4316 & 1.4316 & 1.3985 & 1.3985 & 1.3679 & 1.3679 & 1.3398 & 1.3398 \\
\hline 308.15 & 1.4678 & 1.4678 & 1.4266 & 1.4266 & 1.3937 & 1.3937 & 1.3633 & 1.3633 & 1.3352 & 1.3352 \\
\hline 313.15 & 1.4626 & 1.4626 & 1.4219 & 1.4219 & 1.3887 & 1.3887 & 1.3585 & 1.3585 & 1.3306 & 1.3306 \\
\hline
\end{tabular}




\section{Determination of Nominal Standard Uncertainty in Density Measurements.}

Over the temperature range $283.15-313.15 \mathrm{~K}$, we estimate the nominal standard uncertainty of the density measurement to be $\mathrm{u}(\rho)=0.00004 \mathrm{~g} \mathrm{~cm}^{-3}$. This estimate was determined by measuring the density of dodecane, which was obtained from H\&D Fitzgerald Ltd., and comparing the measured values with the certified values (Table S9). A deviation plot of the measured density of dodecane from the certified values in the temperature range of 283.15 $313.15 \mathrm{~K}$ is given in Figure S2. Based on this deviation plot we estimate the nominal relative standard uncertainty of a density measurement over this temperature range to be $\mathrm{u}_{\mathrm{r}}(\rho)=0.00005$.

Table S9. Measured and Certified Density Values of Dodecane as a Function of Temperature at $0.1 \mathrm{MPa}$.

\begin{tabular}{|c|c|c|c|}
\hline $\mathrm{T}(\mathrm{K})$ & \multicolumn{3}{|c|}{$\rho\left(\mathrm{g} \mathrm{cm}^{-3}\right)$} \\
\hline & Measured & Certified & $\Delta \rho$ \\
\hline 283.15 & 0.75611 & 0.75611 & 0 \\
\hline 288.15 & 0.75243 & 0.75249 & $-6 \times 10^{-5}$ \\
\hline 293.15 & 0.74892 & 0.74886 & $6 \times 10^{-5}$ \\
\hline 298.15 & 0.74527 & 0.74523 & $4 \times 10^{-5}$ \\
\hline 303.15 & 0.74168 & 0.74160 & $8 \times 10^{-5}$ \\
\hline 308.15 & 0.73803 & 0.73797 & $6 \times 10^{-5}$ \\
\hline 313.15 & 0.73440 & 0.73432 & $8 \times 10^{-5}$ \\
\hline
\end{tabular}

$\Delta \rho=\rho($ Measured $)-\rho($ Certified $)$

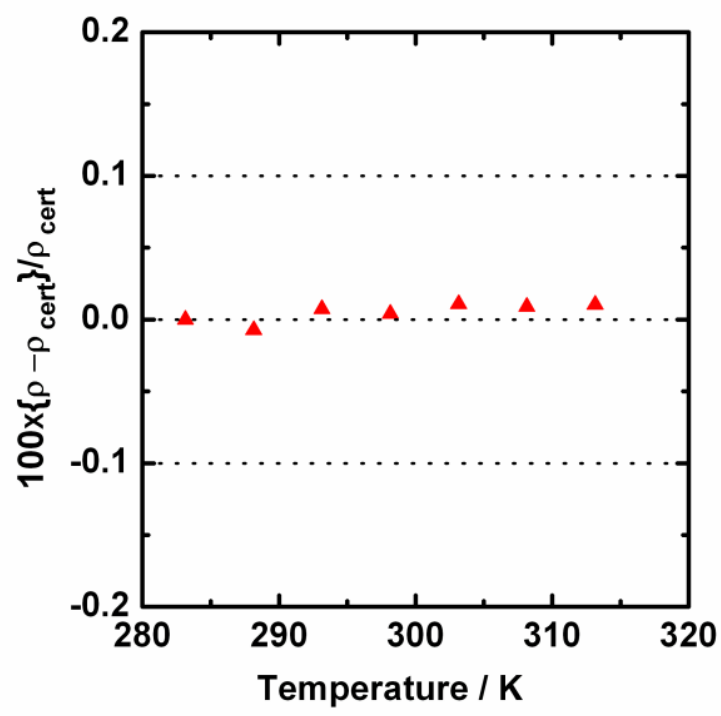

Figure S2. Deviation plot of the measured density of dodecane from the certified values in the temperature range of $283.15-313.15 \mathrm{~K}$. 


\section{Comparison of Densities (Current Work vs. NIST Database) at 298.15 K.}

Table S10. Comparison of the Values of the Densities (units g-cm ${ }^{-3}$ ) of $\left[\mathrm{C}_{\mathrm{N}} \mathrm{C}_{1} \mathrm{im}\right]\left[\mathrm{NTf}_{2}\right]$ in the Current Study with Literature Values at 298.15 K and P =0.1 MPa from NIST Database (http://ilthermo.boulder.nist.gov/).

\begin{tabular}{|c|c|c|c|c|c|}
\hline & \multicolumn{5}{|c|}{ Ionic Liquid } \\
\hline & $\mathrm{C}_{3} \mathrm{C}_{1}$ & $\mathrm{C}_{4} \mathrm{C}_{1}$ & $\mathrm{C}_{5} \mathrm{C}_{1}$ & $\mathrm{C}_{6} \mathrm{C}_{1}$ & $\mathrm{C}_{7} \mathrm{C}_{1}$ \\
\hline Current Work ${ }^{\mathrm{a}}$ & 1.4756 & 1.4369 & 1.4036 & 1.3727 & 1.3454 \\
\hline \multirow{19}{*}{ Literature $^{\mathrm{b}}$} & $1.4757^{7}$ & $1.436^{8}$ & $1.4045^{7}$ & $1.3723^{9}$ & $1.344^{2}$ \\
\hline & $1.47397^{10}$ & $1.43704^{11}$ & & $1.37081^{11}$ & \\
\hline & $1.47444^{12}$ & $1.43664^{13}$ & & $1.371^{14}$ & \\
\hline & $1.47444^{15}$ & $1.4376^{16}$ & & $1.3724^{17}$ & \\
\hline & & $1.4361^{10}$ & & $1.37204^{13}$ & \\
\hline & & $1.4368^{18}$ & & $1.3716^{19}$ & \\
\hline & & $1.4343^{20}$ & & $1.3647^{21}$ & \\
\hline & & $1.4341^{22}$ & & $1.37^{23}$ & \\
\hline & & $1.437^{24}$ & & $1.3721^{25}$ & \\
\hline & & $1.43423^{26}$ & & $1.3722^{27}$ & \\
\hline & & $1.437^{28}$ & & $1.3707^{29}$ & \\
\hline & & $1.43635^{15}$ & & $1.372^{30}$ & \\
\hline & & $1.436^{31}$ & & $1.37164^{26}$ & \\
\hline & & & & $1.371^{3 \Gamma}$ & \\
\hline & & & & $1.391^{32}$ & \\
\hline & & & & $1.37199^{33}$ & \\
\hline & & & & $1.37209^{34}$ & \\
\hline & & & & $1.372^{35}$ & \\
\hline & & & & $1.37209^{36}$ & \\
\hline \multicolumn{6}{|l|}{ Statistics $^{\mathrm{c}}$} \\
\hline Average & 1.4746 & 1.4361 & 1.4045 & 1.3723 & 1.344 \\
\hline Standard Dev. & 0.0007 & 0.0012 & & 0.0048 & \\
\hline $95 \%$ C.L. ${ }^{d}$ & 0.0012 & 0.0007 & 0.0023 & 0.0023 & 0.008 \\
\hline
\end{tabular}

${ }^{\mathrm{a}}$ Standard uncertainty for measured densities in current work - $\mathrm{u}(\rho)=0.00004 \mathrm{~g}-\mathrm{cm}^{-3}$; ${ }^{\mathrm{b}}$ all other rows correspond to literature values in NIST database (see references); ${ }^{c}$ statistics on literature values; ${ }^{\mathrm{d}} 95 \%$ confidence limit. 
10. Plots of Density vs. Temperature (Current Work and NIST Database).

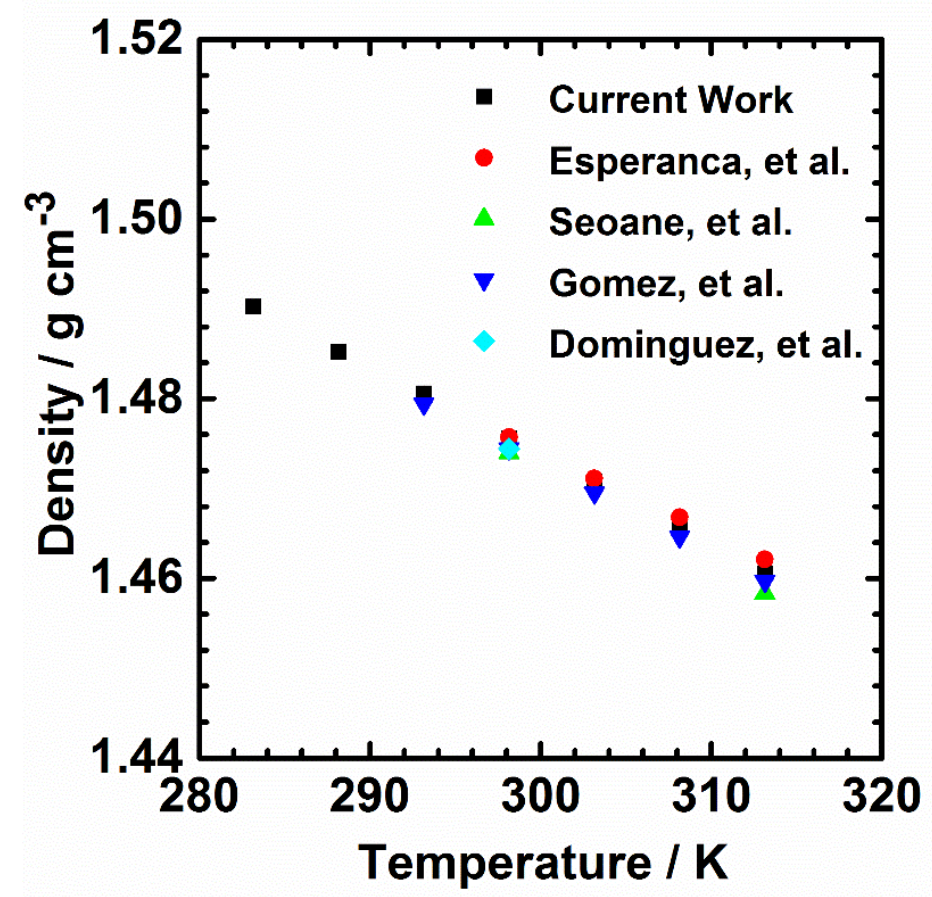

Figure S3. Comparison of the density values of $\left[\mathrm{C}_{3} \mathrm{C}_{1} \mathrm{im}\right]\left[\mathrm{NTf}_{2}\right]$ from the current work with those measured by Esperanca et al., ${ }^{7}$ Seoane et al., ${ }^{10}$ Gomez et al., ${ }^{12}$ and Dominguez et al. ${ }^{15}$ 


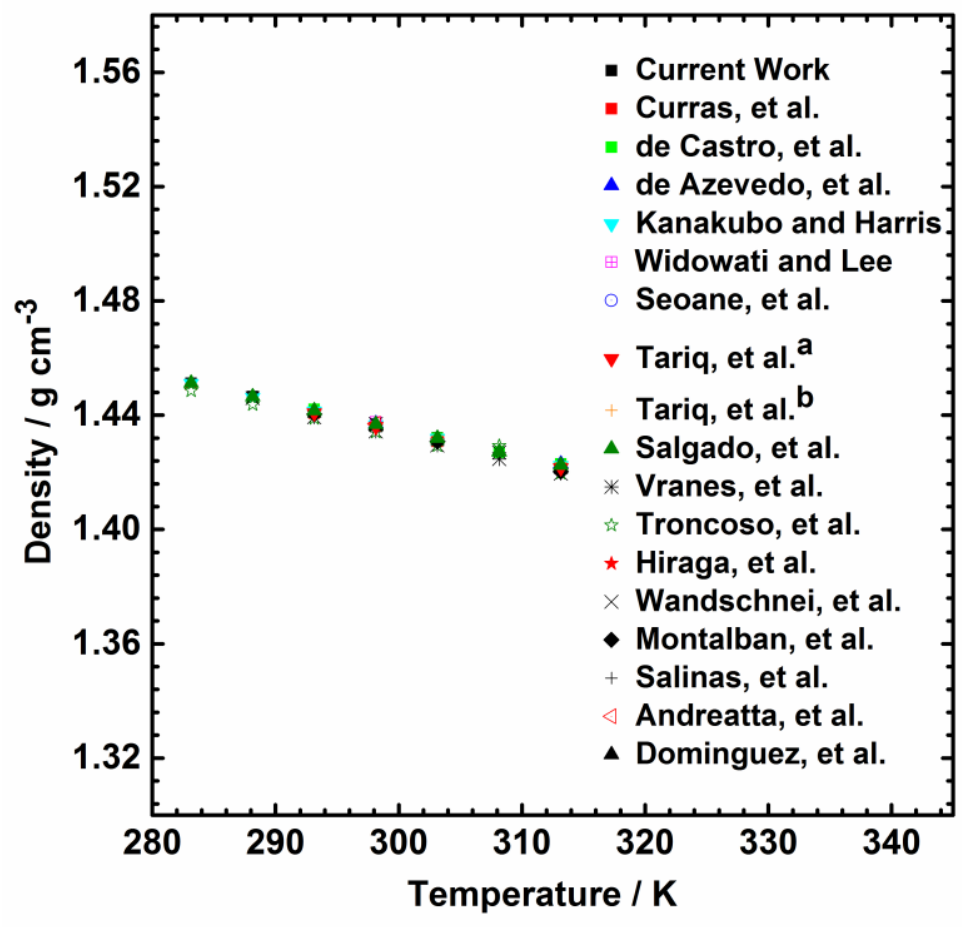

Figure S4. Comparison of the density values of $\left[\mathrm{C}_{4} \mathrm{C}_{1} \mathrm{im}\right]\left[\mathrm{NTf}_{2}\right]$ from the current work with those measured by Curras et al., ${ }^{37}$ de Castro et al., ${ }^{8}$ de Azevedo et al., ${ }^{11}$ Kanakubo and Harris, ${ }^{13}$ Widowati and Lee, ${ }^{16}$ Seoane et al., ${ }^{10}$ Tariq et al.(a), ${ }^{31}$ Tariq et al.(b), ${ }^{38}$ Salgado et al., ${ }^{18}$ Vranes et al., ${ }^{20}$ Troncoso et al., ${ }^{22}$ Hiraga et al., ${ }^{39}$ Wandschenei et al., ${ }^{24}$ Montalban et al., ${ }^{40}$ Salinas et al., ${ }^{26}$ Andreatta et al., ${ }^{28}$ and Dominguez et al. ${ }^{15}$ 


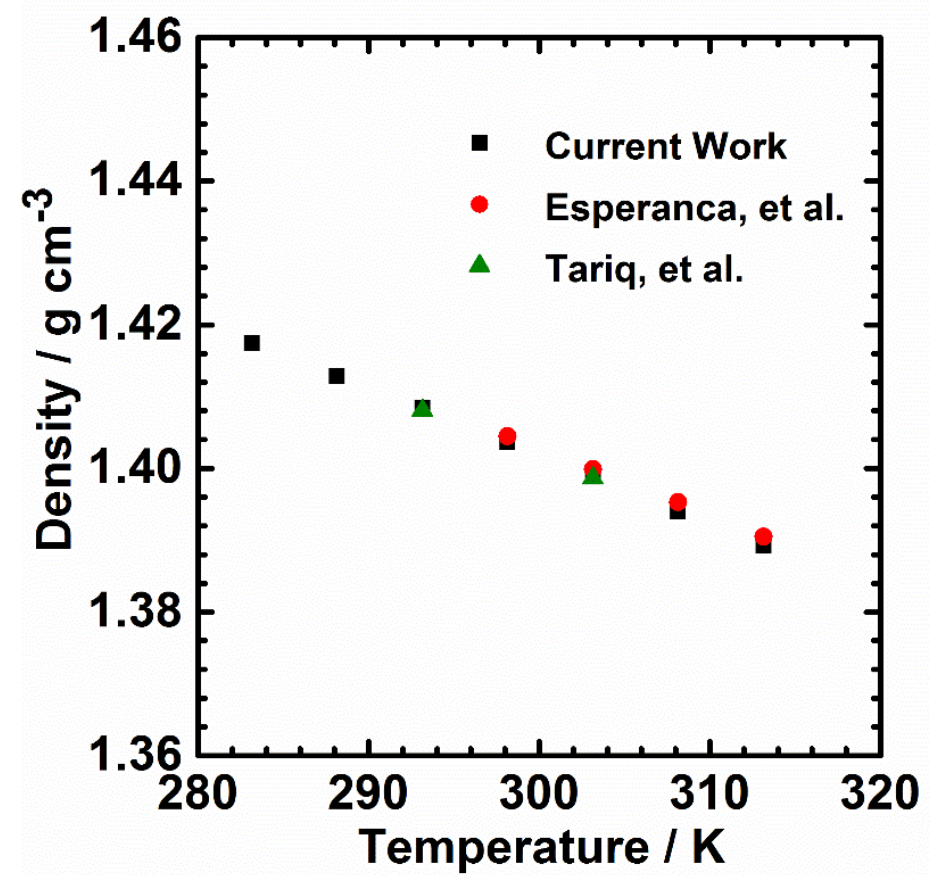

Figure S5. Comparison of the density values of $\left[\mathrm{C}_{5} \mathrm{C}_{1} \mathrm{im}\right]\left[\mathrm{NTf}_{2}\right]$ from the current work with those measured by Esperanca et al., ${ }^{7}$ and Tariq et al. ${ }^{38}$ 


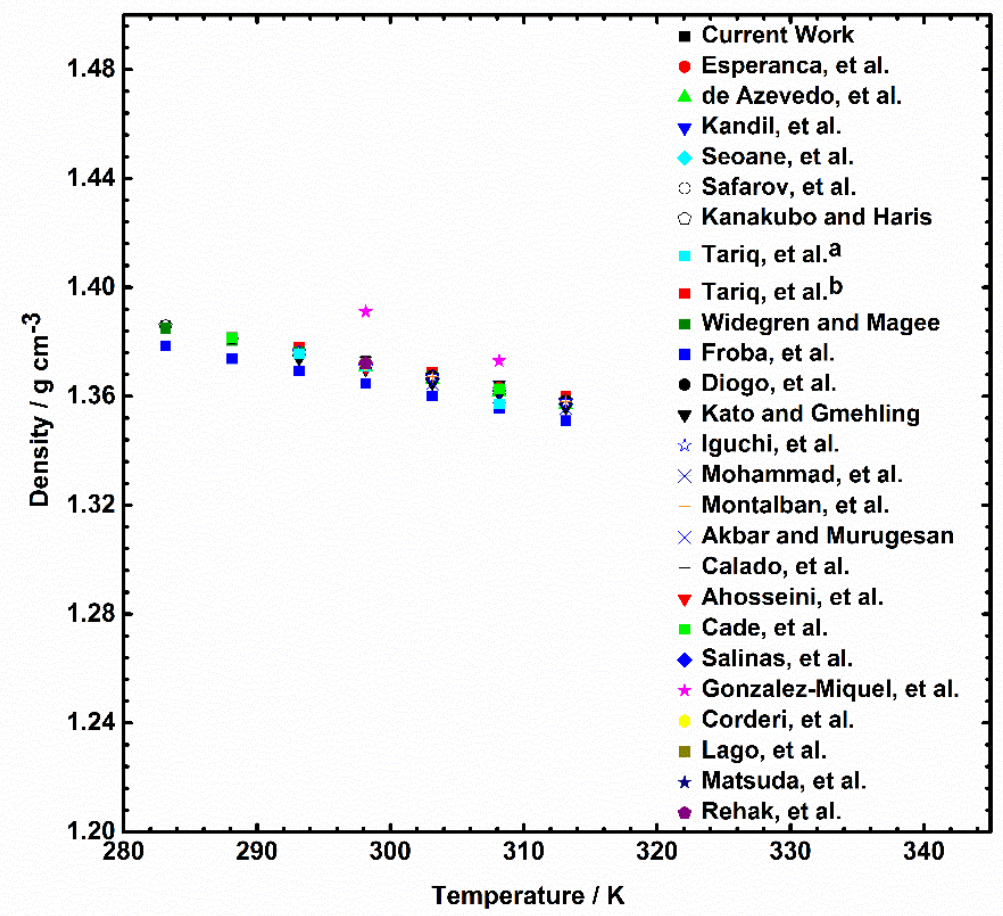

Figure S6. Comparison of the density values of $\left[\mathrm{C}_{6} \mathrm{C}_{1} \mathrm{im}\right]\left[\mathrm{NTf}_{2}\right]$ from the current work with those measured by Esperanca et al., ${ }^{9}$ de Azevedo et al.,de ${ }^{11}$ Kandil et al. ${ }^{14}$ Soeane et al., ${ }^{10}$ Safarov et al., ${ }^{17}$ Kanakubo and Harris, ${ }^{13}$ Tariq et al.(a),${ }^{31}$ Tariq et al.(b),${ }^{38}$ Widegren and Magee,,${ }^{19}$ Froba et al., ${ }^{21}$ Diogo et al., ${ }^{41}$ Kato and Gmehling ${ }^{23}$ Iguchi et al., ${ }^{42}$ Mohammad et al. ${ }^{25}$ Montalban et al., ${ }^{40}$ Akbar and Murugesan, ${ }^{43}$ Calado et al., ${ }^{27}$ Ahosseini et al., ${ }^{29}$ Cade et al.,${ }^{30}$ Salinas et al., ${ }^{26}$ Gonzalez-Miquel., ${ }^{32}$ Corderi et al., ${ }^{33}$ Lago et al., ${ }^{34}$ Matsuda et al. ${ }^{35}$ and Rehak et al. $^{36}$ 


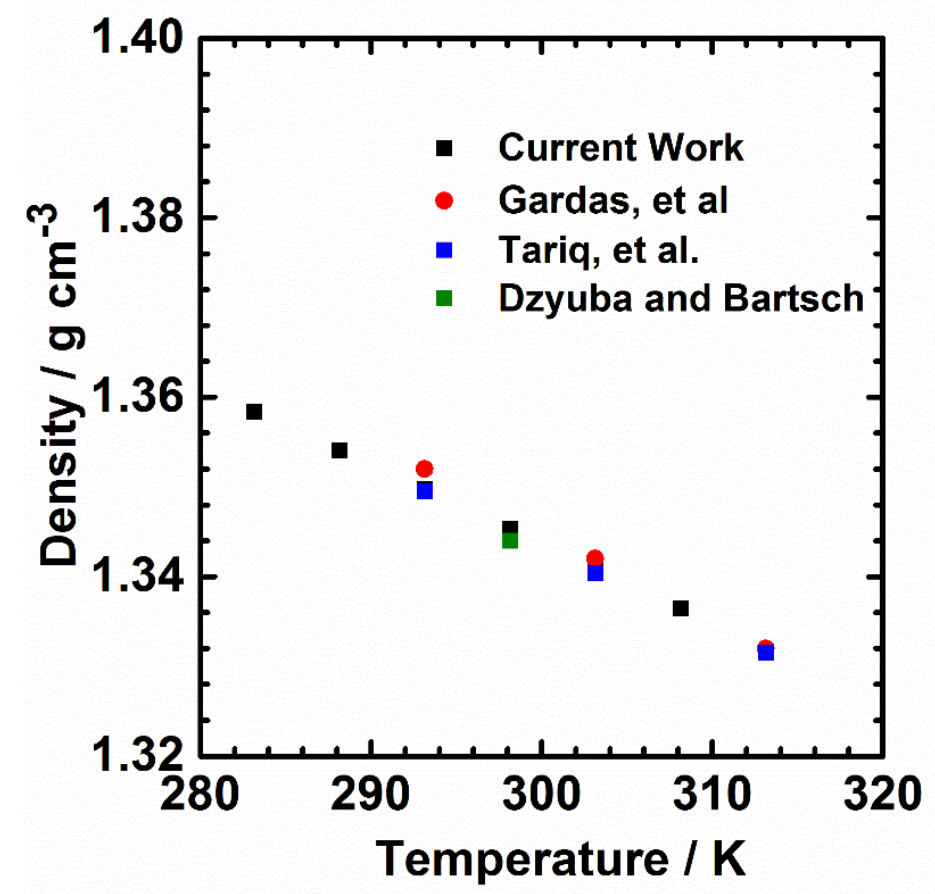

Figure S7. Comparison of the density values of $\left[\mathrm{C}_{7} \mathrm{C}_{1} \mathrm{im}\right]\left[\mathrm{NTf}_{2}\right]$ from the current work with those measured by Gardas et al., ${ }^{44}$ Tariq et al., ${ }^{38}$ and Dzyuba and Bartsch. ${ }^{2}$ 


\section{Comparison of Melting Temperatures and Enthalpies of Fusion (Current Work vs. NIST Database).}

Table S11. Comparison of the Melting Temperatures and Enthalpies of Fusion for 1- $n$-alkyl-3-methylimidazolium bis(trifluoromethanesulfonyl)imides $\left[\mathrm{C}_{\mathrm{n}} \mathrm{C}_{1} \mathrm{im}\right]\left[\mathrm{NTf}_{2}\right]$ from Current Study with those from the Literature in

NIST Database (http://ilthermo.boulder.nist.gov/).

\begin{tabular}{|c|c|c|c|c|c|c|c|c|c|c|}
\hline & \multicolumn{2}{|c|}{$\mathrm{C}_{3} \mathrm{C}_{1}$} & \multicolumn{2}{|c|}{$\mathrm{C}_{4} \mathrm{C}_{1}$} & \multicolumn{2}{|c|}{$\mathrm{C}_{5} \mathrm{C}_{1}$} & \multicolumn{2}{|c|}{$\overline{\mathrm{C}_{6} \mathrm{C}_{1}}$} & \multicolumn{2}{|c|}{$\mathrm{C}_{7} \mathrm{C}_{1}$} \\
\hline & $\begin{array}{l}\mathrm{T}_{\mathrm{m}} \\
\mathrm{K}\end{array}$ & $\begin{array}{c}\Delta \mathrm{H}_{\mathrm{m}} \\
\mathrm{kJ} \cdot \mathrm{mol}^{-1}\end{array}$ & $\begin{array}{l}\mathrm{T}_{\mathrm{m}} \\
\mathrm{K}\end{array}$ & $\begin{array}{c}\Delta \mathrm{H}_{\mathrm{m}} \\
\mathrm{kJ} \cdot \mathrm{mol}^{-1}\end{array}$ & $\begin{array}{l}\mathrm{T}_{\mathrm{m}} \\
\mathrm{K}\end{array}$ & $\begin{array}{c}\Delta \mathrm{H}_{\mathrm{m}} \\
\mathrm{kJ} \cdot \mathrm{mol}^{-1}\end{array}$ & $\begin{array}{l}\mathrm{T}_{\mathrm{m}} \\
\mathrm{K}\end{array}$ & $\begin{array}{c}\Delta \mathrm{H}_{\mathrm{m}} \\
\mathrm{kJ} \cdot \mathrm{mol}^{-1}\end{array}$ & $\begin{array}{l}\mathrm{T}_{\mathrm{m}} \\
\mathrm{K}\end{array}$ & $\begin{array}{c}\Delta \mathrm{H}_{\mathrm{m}} \\
\mathrm{kJ} \cdot \mathrm{mol}^{-1}\end{array}$ \\
\hline Current Work & n.o. & n.o. & 269.6 & 25.0 & 262.6 & 1.3 & 261.9 & 6.9 & 272.2 & 0.37 \\
\hline \multirow{13}{*}{ Literature $^{\mathrm{e}}$} & & & $270.22^{45}$ & $23.78^{45}$ & $264.15^{2}$ & 1.1 & $265.8^{46 a}$ & $2.19^{46 a}$ & $280.1^{2}$ & $0.4^{2}$ \\
\hline & & & $267.15^{2}$ & $7.0^{2}$ & $267.1^{47}$ & & $272.11^{46 b}$ & $27.83^{46 b}$ & & \\
\hline & & & $269.2^{47}$ & & & & $264^{48}$ & & & \\
\hline & & & $270.35^{49}$ & & & & $266^{50}$ & & & \\
\hline & & & $271.1^{51}$ & & & & $267^{52}$ & $4.6^{52}$ & & \\
\hline & & & $270.1^{52}$ & $20.9^{52}$ & & & $272.1^{53}$ & & & \\
\hline & & & $267.61^{54 c}$ & $22.43^{54 c}$ & & & $272.03^{55}$ & & & \\
\hline & & & $268.51^{54 d}$ & $24.53^{54 d}$ & & & $265^{56}$ & & & \\
\hline & & & $269^{48}$ & & & & $271^{56}$ & & & \\
\hline & & & $269^{3}$ & & & & $271^{57}$ & $27.7^{57}$ & & \\
\hline & & & $270.22^{55}$ & & & & $272^{58}$ & $28.09^{58}$ & & \\
\hline & & & & & & & $265.9^{47}$ & & & \\
\hline & & & & & & & $271.3^{59}$ & & & \\
\hline
\end{tabular}

${ }^{\mathrm{a}}$ Metastable crystal-crystal; ${ }^{46 \mathrm{~b}}$ crystal-liquid; ${ }^{46 \mathrm{c}}$ QUILL Centre sample; ${ }^{\mathrm{d}}$ Covalent Associates sample; ${ }^{\mathrm{e}}$ see References. 


\section{DSC curves of Linear and Branched ILs.}

The DSC curves of $\left[\mathrm{C}_{3} \mathrm{C}_{1} \mathrm{im}\right]\left[\mathrm{NTf}_{2}\right]$ and $\left[\mathrm{C}_{5} \mathrm{C}_{1} \mathrm{im}\right]\left[\mathrm{NTf}_{2}\right]$ were given in a previously paper. ${ }^{60}$ The DSC curves of $\left[\mathrm{C}_{4} \mathrm{C}_{1} \mathrm{im}\right]\left[\mathrm{NTf}_{2}\right]$ and $\left[\mathrm{C}_{6} \mathrm{C}_{1} \mathrm{im}\right]\left[\mathrm{NTf}_{2}\right]$ are presented in Figures 6 and $5 \mathrm{a}$ of the article. The DSC curves of $\left[1 \mathrm{mC}_{2} \mathrm{C}_{1} \mathrm{im}\right]\left[\mathrm{NTf}_{2}\right]$ and $\left[2 \mathrm{mC}_{3} \mathrm{C}_{1} \mathrm{im}\right]\left[\mathrm{NTf}_{2}\right]$ are also shown in Figures 7 and $5 \mathrm{~b}$ of the article. To complete this set, DSC curves for the $\mathrm{ILs}_{[}\left[\mathrm{C}_{7} \mathrm{C}_{1} \mathrm{im}\right]\left[\mathrm{NTf}_{2}\right]$, $\left[3 \mathrm{mC}_{4} \mathrm{C}_{1} \mathrm{im}\right]\left[\mathrm{NTf}_{2}\right],\left[4 \mathrm{mC}_{5} \mathrm{C}_{1} \mathrm{im}\right]\left[\mathrm{NTf}_{2}\right]$ and $\left[5 \mathrm{mC}_{6} \mathrm{C}_{1} \mathrm{im}\right]\left[\mathrm{NTf}_{2}\right]$ are plotted in Figures S8-S11.

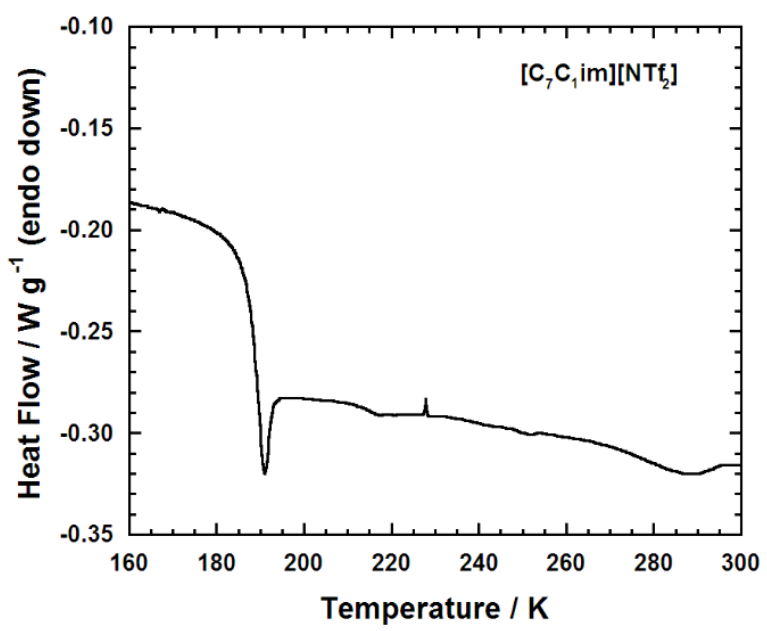

Figure S8. DSC heating curve of $\left[\mathrm{C}_{7} \mathrm{C}_{1} \mathrm{im}\right]\left[\mathrm{NTf}_{2}\right](10 \mathrm{~K} / \mathrm{min}$ cooling, $10 \mathrm{~K} / \mathrm{min}$ heating).

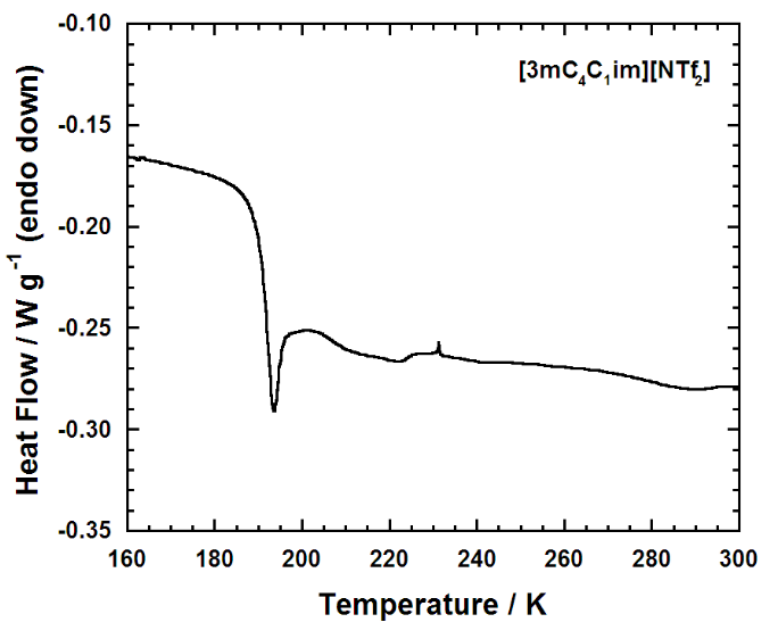

Figure S9. DSC heating curve of $\left[3 \mathrm{mC}_{4} \mathrm{C}_{1} \mathrm{im}\right]\left[\mathrm{NTf}_{2}\right](10 \mathrm{~K} / \mathrm{min}$ cooling, $10 \mathrm{~K} / \mathrm{min}$ heating). 


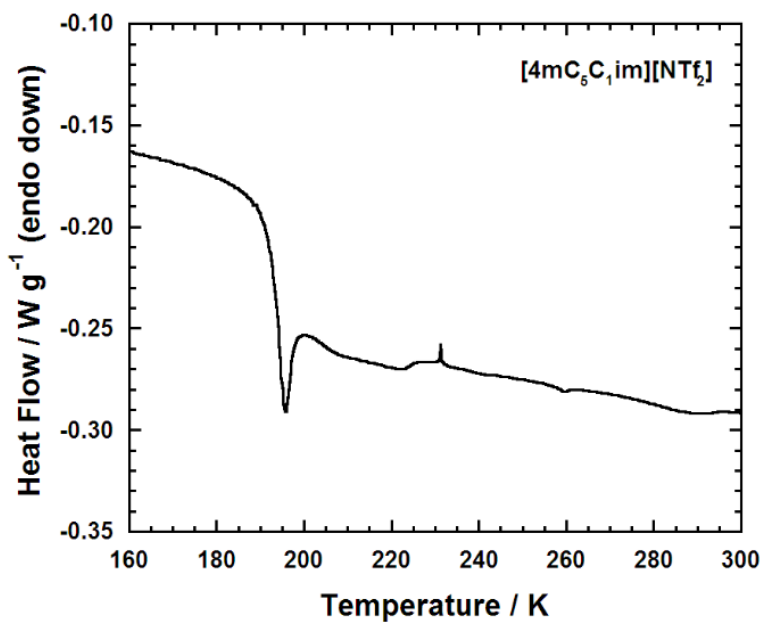

Figure S10. DSC heating curve of $\left[4 \mathrm{mC}_{5} \mathrm{C}_{1} \mathrm{im}\right]\left[\mathrm{NTf}_{2}\right](10 \mathrm{~K} / \mathrm{min}$ cooling, $10 \mathrm{~K} / \mathrm{min}$ heating $)$.

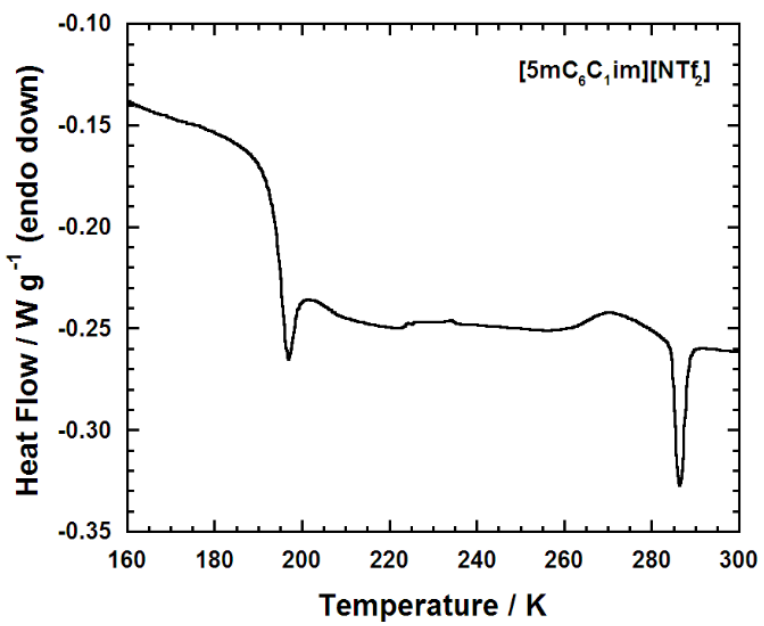

Figure S11. DSC heating curve of $\left[5 \mathrm{mC}_{6} \mathrm{C}_{1} \mathrm{im}\right]\left[\mathrm{NTf}_{2}\right](10 \mathrm{~K} / \mathrm{min}$ cooling, $10 \mathrm{~K} / \mathrm{min}$ heating $)$. 
13. Comparison of Viscosities at 298.15 K (Current Work and NIST database).

Table S12. Comparison of the Values of the Viscosities (units mPa.s) of $\left[\mathrm{C}_{\mathrm{N}} \mathrm{C}_{1} \mathrm{im}\right]\left[\mathrm{NTf}_{2}\right]$ in the Current Study to NIST Database Values at $298.15 \mathrm{~K}$ and P $=0.1 \mathrm{MPa}$.

\begin{tabular}{|c|c|c|c|c|c|}
\hline & \multicolumn{5}{|c|}{ Ionic Liquid } \\
\hline & $\mathrm{C}_{3} \mathrm{C}_{1}$ & $\mathrm{C}_{4} \mathrm{C}_{1}$ & $\mathrm{C}_{5} \mathrm{C}_{1}$ & $\mathrm{C}_{6} \mathrm{C}_{1}$ & $\mathrm{C}_{7} \mathrm{C}_{1}$ \\
\hline Current Work $^{\mathrm{a}}$ & 43.0 & 50.9 & 61.3 & 73.3 & 82 \\
\hline \multirow{18}{*}{ Literature $^{\mathrm{b}}$} & $43.7^{12}$ & $50.1^{20}$ & $57.8^{61}$ & $71^{62}$ & $81.1^{61}$ \\
\hline & $45.7^{63}$ & $50.6^{61}$ & $62.4^{63}$ & $70.1^{64}$ & $81.4^{63}$ \\
\hline & $45.7^{61}$ & $51.2^{26}$ & $61.5^{65}$ & $69.5^{66}$ & $84.3^{65}$ \\
\hline & $43.7^{65}$ & $51.6^{18}$ & & $68^{50}$ & \\
\hline & & $49.6^{67}$ & & $70.9^{68}$ & \\
\hline & & $50.5^{63}$ & & $65^{63}$ & \\
\hline & & $51.7^{65}$ & & $67.8^{52}$ & \\
\hline & & $50.4^{69}$ & & $68^{14}$ & \\
\hline & & $50.7^{70}$ & & $68^{25}$ & \\
\hline & & & & $80.7^{71}$ & \\
\hline & & & & $70.5^{26}$ & \\
\hline & & & & $69.3^{72}$ & \\
\hline & & & & $70.6^{61}$ & \\
\hline & & & & $70.3^{19}$ & \\
\hline & & & & $72.2^{65}$ & \\
\hline & & & & $71.1^{73}$ & \\
\hline & & & & $71.0^{74}$ & \\
\hline & & & & $80.1^{75}$ & \\
\hline \multicolumn{6}{|l|}{ Statistics $^{\mathrm{c}}$} \\
\hline Average & 44.7 & 50.6 & 60.6 & 70.8 & 82.3 \\
\hline Standard Dev. & 1.2 & 0.7 & 2.4 & 3.9 & 1.8 \\
\hline $95 \%$ C.L. $^{d}$ & 1.8 & 0.5 & 6.0 & 1.9 & 4.4 \\
\hline
\end{tabular}

${ }^{a}$ Standard uncertainty for viscosities in current work $-\mathrm{u}(\eta)=2.0 \mathrm{mPa} \cdot \mathrm{s} ;{ }^{\mathrm{b}}$ all other rows correspond to literature values in the NIST database (see references); ${ }^{c}$ statistics on literature values; ${ }^{\mathrm{d}} 95 \%$ confidence limit; 
14. Plots of Viscosity vs. Temperature (Current work and NIST Database).

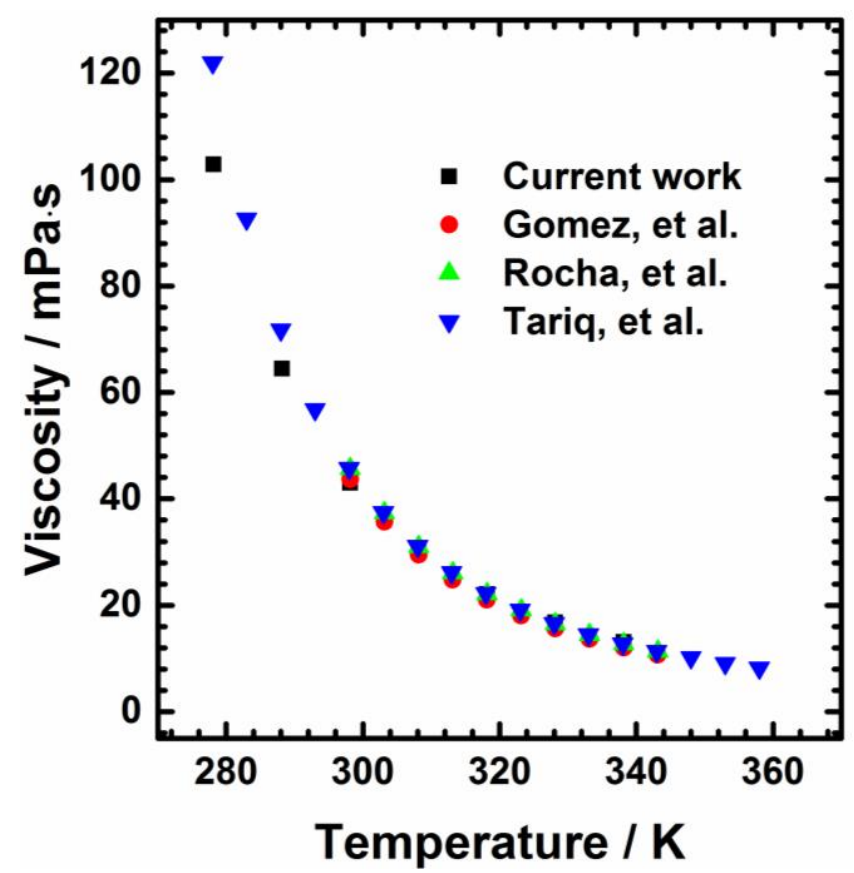

Figure S12. Comparison of the viscosity values of $\left[\mathrm{C}_{3} \mathrm{C}_{1} \mathrm{im}\right]\left[\mathrm{NTf}_{2}\right]$ from the current work with those measured by Gomez et al., ${ }^{12}$ Rocha et al., ${ }^{63}$ and Tariq et al. ${ }^{61}$

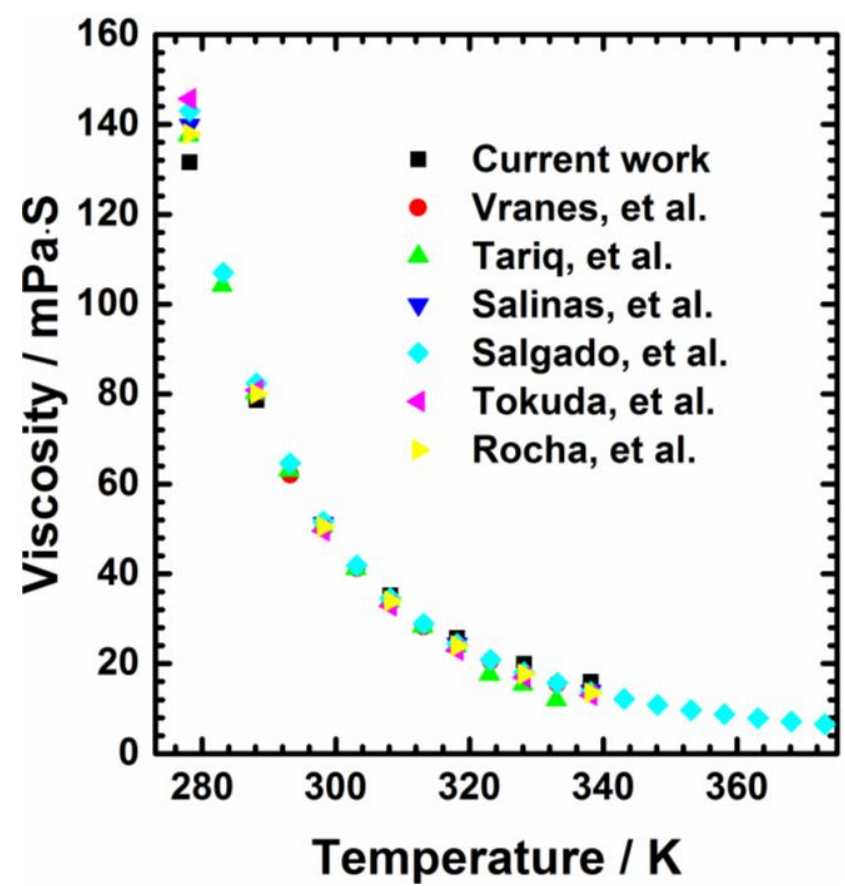

Figure S13. Comparison of the viscosity values of $\left[\mathrm{C}_{4} \mathrm{C}_{1} \mathrm{im}\right]\left[\mathrm{NTf}_{2}\right]$ from the current work with those measured by Vranes et al., ${ }^{20}$ Tariq et al., ${ }^{61}$ Salinas et al., ${ }^{26}$ Salgado et al.. ${ }^{18}$ Tokuda et al., ${ }^{52}$ and Rocha et al. ${ }^{63}$ 


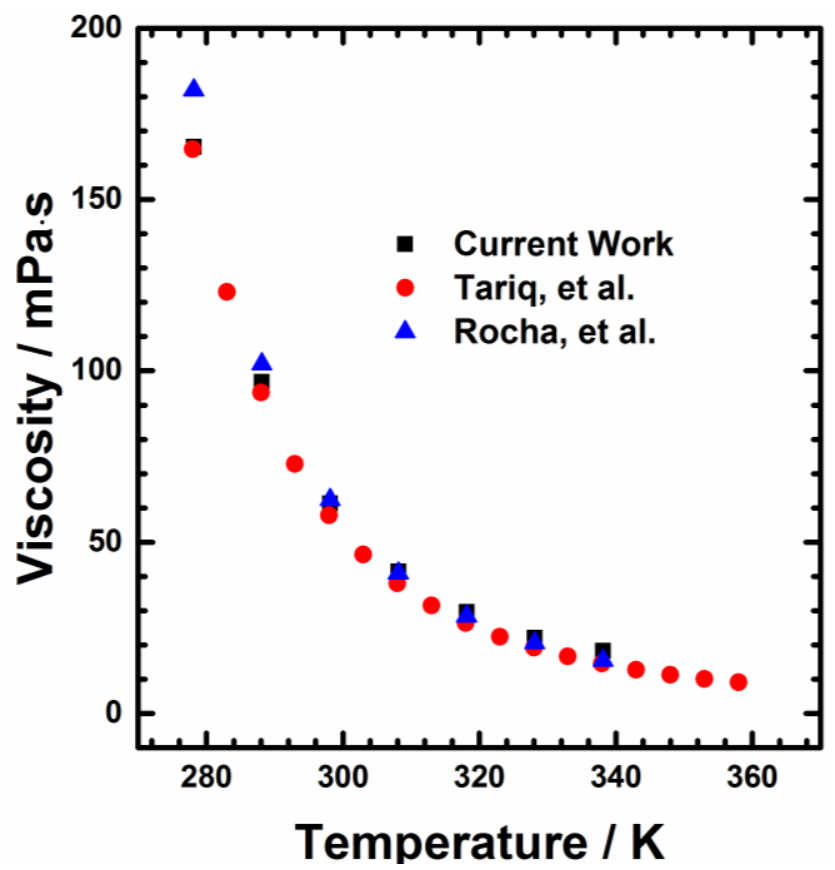

Figure S14. Comparison of the viscosity values of $\left[\mathrm{C}_{5} \mathrm{C}_{1} \mathrm{im}\right]\left[\mathrm{NTf}_{2}\right]$ from the current work with those measured by Tariq et al. ${ }^{61}$ and Rocha et al. ${ }^{63}$

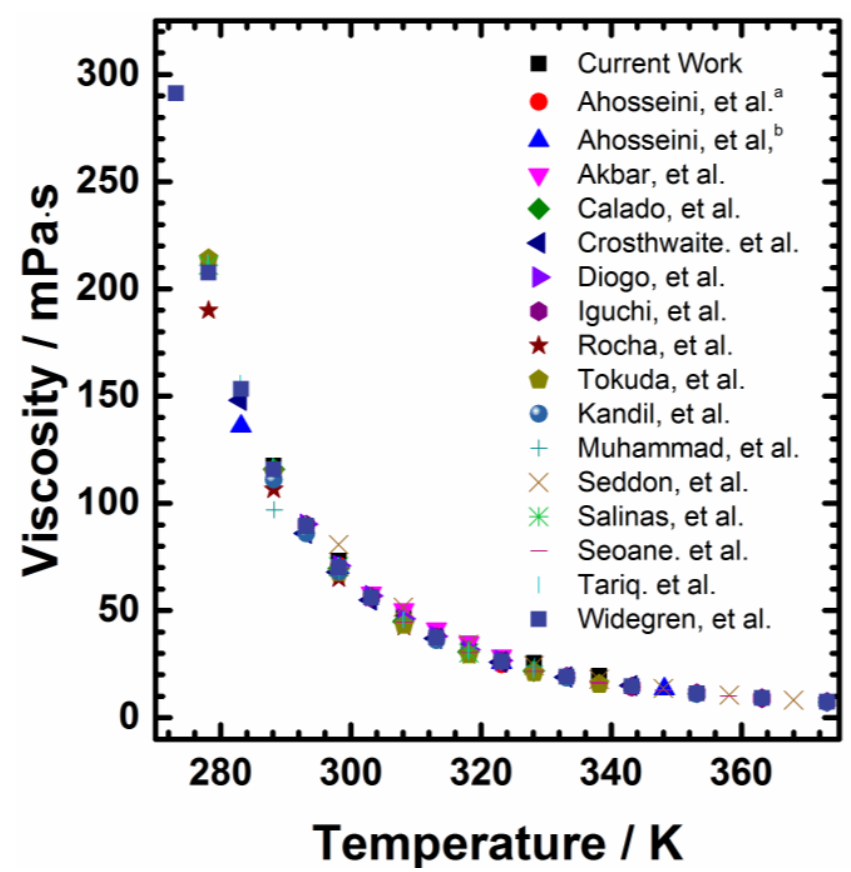

Figure S15. Comparison of the viscosity values of $\left[\mathrm{C}_{6} \mathrm{C}_{1} \mathrm{im}\right]\left[\mathrm{NTf}_{2}\right]$ from the current work with those measured by Ahosseini et al., ${ }^{62}$ Ahosseini et al., ${ }^{64}$ Akbar et al., ${ }^{43}$ Calado et al., ${ }^{66}$ Crosthwaite et al., ${ }^{50}$ Diogo et al., ${ }^{68}$ Iguchi et al., ${ }^{42}$ Rocha et al., ${ }^{63}$ Tokuda et al., ${ }^{52}$ Kandil et al., ${ }^{14}$ Muhammad et al., ${ }^{25}$ Seddon et al., ${ }^{71}$ Salinas et al., ${ }^{26}$ Soeane et al., ${ }^{72}$ Tariq et al. ${ }^{61}$ and Widegren et al. $^{19}$ 


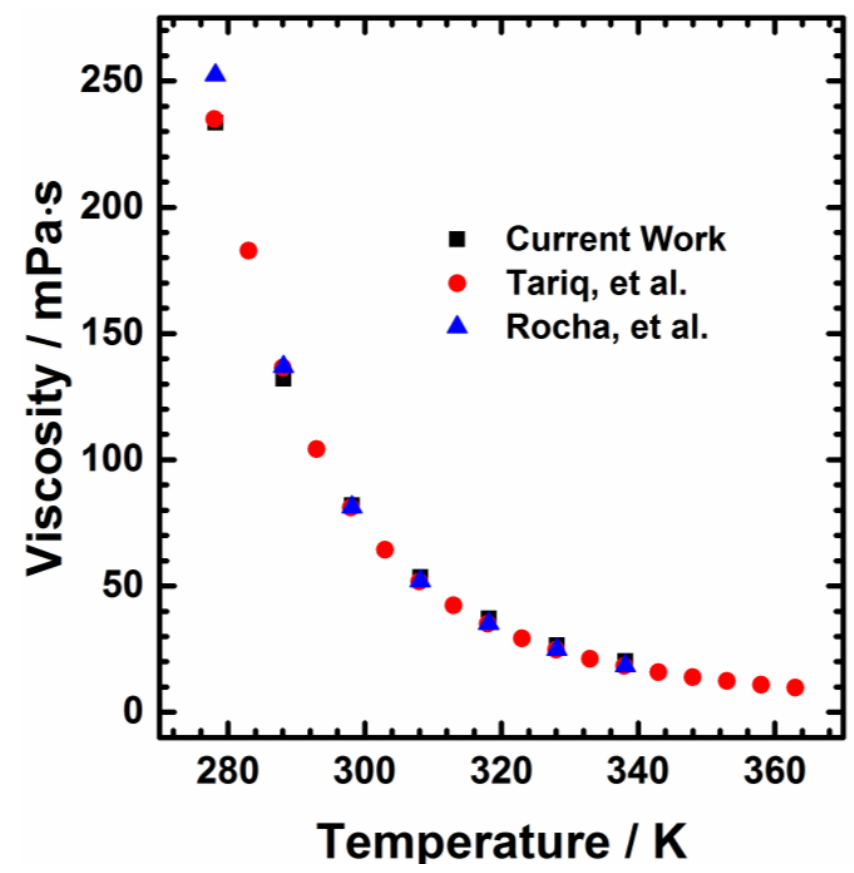

Figure S16. Comparison of the viscosity values of $\left[\mathrm{C}_{7} \mathrm{C}_{1} \mathrm{im}\right]\left[\mathrm{NTf}_{2}\right]$ from the current work with those measured by Tariq et al. ${ }^{61}$ and Rocha et al. ${ }^{63}$

\section{Viscosity of [ $\left.2 \mathrm{mC}_{3} \mathrm{C}_{1} \mathrm{im}\right]\left[\mathrm{NTf}_{2}\right]$ : Batches $1,2 \mathrm{a}$, and $2 \mathrm{~b}$.}

Thinking that impurities in the starting material (undetectable by NMR) could be the cause of the anomalously high viscosity of $2 \mathrm{mC}_{3} \mathrm{C}_{1}$, we synthesized a second batch of $2 \mathrm{mC}_{3} \mathrm{C}_{1}$ using 2methylpropyl bromide obtained from Sigma-Aldrich (Batch 2a). Given that it is the common starting material for all the other ILs, methylimidazole was ruled out. A third measurement was made on a sample from Batch 2 (Batch $2 b$ ). The viscosities of Batch $2 a$ and $2 b$ are within the standard uncertainty of the measurements the same as that of Batch 1 . The values given Table 5 in the article for $2 \mathrm{mC}_{3} \mathrm{C}_{1}$ are those of Batch 2. Table $\mathrm{S} 14$ gives the parameters for fits of the VFT equation, $\eta=\eta_{0} \exp \left[\mathrm{B} /\left(\mathrm{T}-\mathrm{T}_{0}\right)\right]$, to the viscosities of the three samples.

Table S13. Viscosity (mPa.s) of $\left[2 \mathrm{mC}_{3} \mathrm{C}_{1} \mathrm{im}\right]\left[\mathrm{NTf}_{2}\right]$ as a Function of Temperature at $\mathrm{P}=0.1$ $\mathrm{MPa}$.

\begin{tabular}{|c|c|c|c|c|c|c|c|c|}
\hline & 278.15 & 283.15 & 288.15 & 293.15 & 303.15 & 313.15 & 323.15 & 333.15 \\
& $\mathrm{~K}$ & $\mathrm{~K}$ & $\mathrm{~K}$ & $\mathrm{~K}$ & $\mathrm{~K}$ & $\mathrm{~K}$ & $\mathrm{~K}$ & $\mathrm{~K}$ \\
\hline Batch 1 & --- & 186.2 & 137.5 & 103.2 & 62.7 & 41.0 & 28.3 & 20.7 \\
\hline Batch 2a & 258.2 & 184.4 & 135.0 & 100.8 & 59.5 & 39.5 & 26.6 & --- \\
\hline Batch 2b & 264 & 189.0 & 138.6 & 111.1 & 62.6 & 40.3 & 27.5 & 19.7 \\
\hline
\end{tabular}


Table S14. VFT Fit Parameters for Viscosity of $\left[2 \mathrm{mC}_{3} \mathrm{C}_{1} \mathrm{im}\right]\left[\mathrm{NTf}_{2}\right]$.

\begin{tabular}{|c|c|c|c|}
\hline & $\eta_{0} / \mathrm{mPa} \cdot \mathrm{s}$ & $\mathrm{B} / \mathrm{K}$ & $\mathrm{T}_{0} / \mathrm{K}$ \\
\hline Batch 1 & $0.12 \pm 0.04$ & $822 \pm 77$ & $170 \pm 5$ \\
\hline Batch 2a & $0.07 \pm 0.04$ & $1007 \pm 160$ & $154 \pm 11$ \\
\hline Batch 2b & $0.11 \pm 0.05$ & $853 \pm 19$ & $168 \pm 3$ \\
\hline
\end{tabular}

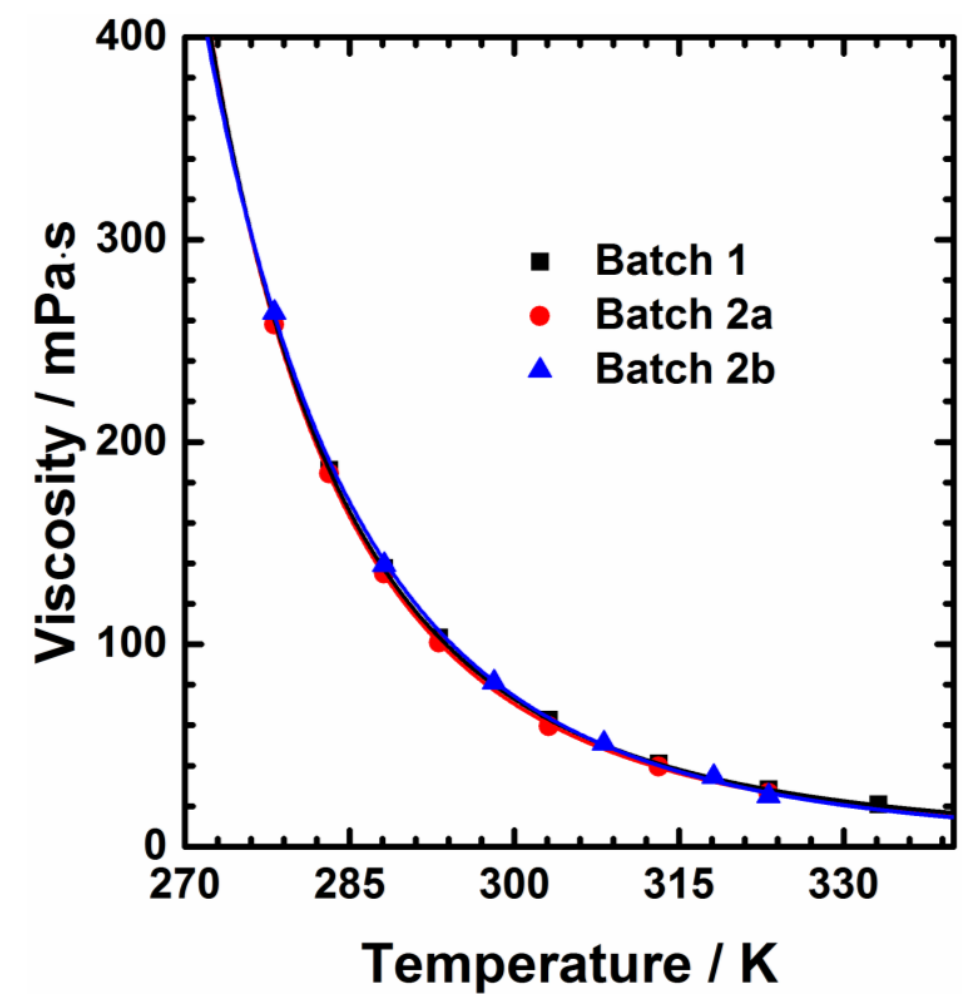

Figure S17. Viscosity of $\left[2 \mathrm{mC}_{3} \mathrm{C}_{1} \mathrm{im}\right]\left[\mathrm{NTf}_{2}\right]$ synthesized using 2-methylpropyl bromide from Acros Organics (Batch 1) and from Sigma Aldrich (Batches 2a and 2b). Black, red, and blue lines are fits of VFT equation to viscosities of the three measurements, respectively. The See Table S14 for VFT fit parameters. 


\section{References}

1. Dzyuba, S. V.; Bartsch, R. A., Efficient Synthesis of 1-Alkyl(aryalky)-3-methy(ethyl)imidazolium Halides: Precursors for Room Temperature Ionic Liquids. J. Heterocyclic Chem. 2001, 38, 265268.

2. $\quad$ Dzyuba, S. V.; Bartsch, R. A., Influence of Structural Variations in 1-Alkyl(aralky)-3methylimidazolium Hexaphosphates and Bis[(trifluoromethane)sulfonyl]amides on Physical Properties of the lonic Liquids. ChemPhysChem 2002, 3, 161-166.

3. Bonhote, P.; Dias, A.-P.; Papageorgiou, N.; Kalyansundaram, K.; Gratzel, M., Hydrophobic, Highly Conductive Ambient-Temperature Molten Salts. Inorg. Chem. 1996, 35, 1168-1178.

4. Ashcroft, S. J.; Booker, D. R.; Turner, J. C. R., Density Measurement by Oscillating Tube. Effects of Viscosity, Temperature, Calibration and Signal Processing. J. Chem. Soc., Faraday Trans. 1990, 86, 145-149.

5. Sanmamed, Y. A.; Gonzalez-Salgado, D.; Troncoso, J.; Cerdierina, C. A.; Romani, L., Viscosityinduced errors in the density determination of room temperature ionic liquids using vibrating tube densitometry. Fluid Phase Equilib. 2007, 252, 96-102.

6. Sanmamed, Y. A.; Gonzalez-Salgado, D.; Troncoso, J.; Romani, L.; Baylaucq, A.; Boned, C. J., Experimental Methodology for Precise determination of density of RTILs as a Function of Temperature and Pressure using Vibrating Tube Densimeters. J. Chem. Thermodyn. 2010, 42, 553-563.

7. Esperança, J. M.; Visak, Z. P.; Plechkova, N. V.; Seddon, K. R.; Guedes, H. J.; Rebelo, L. P., Density, Speed of Sound, and Derived Thermodynamic Properties of Ionic Liquids over an Extended Pressure Range. 4.[C3mim][NTf2] and [C5mim][NTf2]. J. Chem. Eng. Data 2006, 51, 2009-2015.

8. de Castro, C. A. N.; Langa, E.; Morais, A. L.; Lopes, M. L. M.; Lourenço, M. J.; Santos, F. J.; Santos, M. S. C.; Lopes, J. N. C.; Veiga, H. I.; Macatrão, M., Studies on the density, heat capacity, surface tension and infinite dilution diffusion with the ionic liquids $\left[\mathrm{C}_{4} \mathrm{mim}\right]\left[\mathrm{NTf}_{2}\right],\left[\mathrm{C}_{4} \mathrm{mim}\right][\mathrm{dca}],\left[\mathrm{C}_{2} \mathrm{mim}\right]\left[\mathrm{EtOSO}_{3}\right]$ and [Aliquat][dca]. Fluid Phase Equilib. 2010, 294, 157-179.

9. Esperança, J. M.; Guedes, H. J.; Lopes, J. N. C.; Rebelo, L. P. N., Pressure-Density-Temperature $(p-\rho-T)$ Surface of $\left[C_{6} \mathrm{mim}\right]\left[\mathrm{NTf}_{2}\right]$. J. Chem. Eng. Data 2008, 53, 867-870.

10. Seoane, R. G.; González, E. J.; González, B., 1-Alkyl-3-methylimidazolium bis (trifluoromethylsulfonyl) imide ionic liquids as solvents in the separation of azeotropic mixtures. J. Chem. Thermodyn. 2012, 53, 152-157.

11. de Azevedo, R. G.; Esperanca, J.; Szydlowski, J.; Visak, Z.; Pires, P.; Guedes, H.; Rebelo, L., Thermophysical and thermodynamic properties of ionic liquids over an extended pressure range:[bmim][NTf 2] and [hmim][NTf 2]. J. Chem. Thermodyn. 2005, 37, 888-899.

12. Gomez, E.; Calvar, N.; Macedo, E. A.; Dominguez, A., Effect of the temperature on the physical properties of pure 1-propyl 3-methylimidazolium bis(trifluoromethylsulfonyl)imide and characterization of its binary mixtures with alcohols. J. Chem. Thermodyn. 2012, 45, 9-15.

13. Kanakubo, M.; Harris, K. R., Density of 1-Butyl-3-methylimidazolium Bis(trifluoromethanesulfonyl)amide and 1-Hexyl-3-methylimidazolium Bis(trifluoromethanesulfonyl)amide over an Extended Pressure Range up to $250 \mathrm{MPa}$. J. Chem. Eng. Data 2015, 60, 1408-1418.

14. Kandil, M. E.; Marsh, K. N., Measurement of the Viscosity, Density, and Electrical Conductivity of 1-Hexyl-3-methylimidazolium Bis(trifluorosulfonyl)imide at Temperatures between (288 and 433) $\mathrm{K}$ and Pressures below 50 MPa. J. Chem. Eng. Data 2007, 52, 2382-2387. 
15. Domínguez, I.; González, E. J.; González, R.; Domínguez, Á., Extraction of Benzene from Aliphatic Compounds Using Commercial Ionic Liquids as Solvents: Study of the Liquid-Liquid Equilibrium at $\mathrm{T}=298.15 \mathrm{~K}$. J. Chem. Eng. Data 2011, 56, 3376-3383.

16. Widowati, E.; Lee, M.-J., P-V-T properties of binary mixtures of the ionic liquid 1-butyl-3methylimidazolium bis (trifluoromethylsulfonyl) imide with anisole or acetophenone at elevated pressures. J. Chem. Eng. Data 2013, 63, 95-101.

17. Safarov, J.; Hamidova, R.; Zepik, S.; Schmidt, H.; Kul, I.; Shahverdiyev, A.; Hassel, E., Thermophysical properties of 1-hexyl-3-methylimidazolium bis (trifluoromethylsulfonyl) imide at high temperatures and pressures. J. Mol. Liq. 2013, 187, 137-156.

18. Salgado, J.; Regueira, T.; Lugo, L.; Vijande, J.; Fernandez, J.; Garcia, J., Density and viscosity of three (2,2,2-trifluoroethanol +1-butyl-3-methylimidazolium) ionic liquid binary systems. J. Chem. Thermodyn. 2014, 70, 101-110.

19. Widegren, J. A.; Magee, J. W., Density, Viscosity, Speed of Sound, and Electrolytic Conductivity for the Ionic Liquid 1-Hexyl-3-methylimidazolium Bis(trifluoromethylsulfonyl)imide and Its Mixtures with Water. J. Chem. Eng. Data 2007, 52, 2331-2338.

20. Vranes, M.; Papovic, S.; Tot, A.; Zec, N.; Gadzuric, S., Density, excess properties, electrical conductivity and viscosity of 1-butyl-3-methylimidazolium bis(trifluoromethylsulfonyl)imide + cbutyrolactone binary mixtures. J. Chem. Thermodyn. 2014, 76, 161-171.

21. Fröba, A.; Rausch, M.; Krzeminski, K.; Assenbaum, D.; Wasserscheid, P.; Leipertz, A., Thermal Conductivity of Ionic Liquids: Measurement and Prediction. Int. J. Thermophys. 2010, 31, 20592077.

22. Troncoso, J.; Cerdeirina, C. A.; Sanmamed, Y. A.; Romani, L.; Rebelo, L. P. N., Thermodynamic Properties of Imidazolium-Based Ionic Liquids: Densities, Heat Capacities, and Enthalpies of Fusion of [bmim][ PF6] and [bmim][ NTf2]. J. Chem. Eng. Data 2006, 51, 1856-1859.

23. Kato, R.; Gmehling, J., Systems with ionic liquids: Measurement of VLE and $\gamma \infty$ data and prediction of their thermodynamic behavior using original UNIFAC, mod. UNIFAC (Do) and COSMO-RS (OI). J. Chem. Thermodyn. 2005, 37, 603-619.

24. Wandschneider, A.; Lehmann, J. K.; Heintz, A., Surface Tension and Density of Pure lonic Liquids and Some Binary Mixtures with 1-Propanol and 1-Butanol. J. Chem. Eng. Data 2008, 53, 596-599.

25. Muhammad, A.; Mutalib, M.; Wilfred, C. D.; Murugesan, T.; Shafeeq, A., Thermophysical properties of 1-hexyl-3-methyl imidazolium based ionic liquids with tetrafluoroborate, hexafluorophosphate and bis(trifluoromethylsulfonyl)imide anions. J. Chem. Thermodyn. 2008, 40, 1433-1438.

26. Salinas, R.; Pla-Franco, J.; Lladosa, E.; Monton, J. B., Density, Speed of Sound, Viscosity, and Excess Properties of Binary Mixtures Formed by Ethanol and Bis(trifluorosulfonyl)imide-Based Ionic Liquids. J. Chem. Eng. Data 2015, 60, 525-540.

27. Calado, M. S.; Branco, A. S.; Diogo, J. C.; Fareleira, J. M.; Visak, Z. P., Solubility, volumetric properties and viscosity of the sustainable systems of liquid poly (ethylene glycol) 200 with imidazolium-and phosphonium-based ionic liquids: Cation and anion effects. J. Chem. Thermodyn. 2015, 80, 79-91.

28. Andreatta, A. E.; Arce, A.; Rodil, E.; Soto, A., Physico-chemical Properties of Binary and Ternary Mixtures of Ethyl Acetate+ Ethanol+ 1-Butyl-3-methyl-imidazolium bis (trifluoromethylsulfonyl) imide at $298.15 \mathrm{~K}$ and Atmospheric Pressure. J. Solution Chem. 2010, 39, 371-383.

29. Ahosseini, A.; Sensenich, B.; Weatherley, L. R.; Scurto, A. M., Phase Equilibrium, Volumetric, and Interfacial Properties of the Ionic Liquid, 1-Hexyl-3-Methylimidazolium

Bis(trifluoromethylsulfonyl)amide and 1-Octene. J. Chem. Eng. Data 2009, 55, 1611-1617. 
30. Cade, E. A.; Saeva, D. R.; Hoffmann, M. M., Comparing Composition-and TemperatureDependent Excess Molar Volumes of Binary Systems Involving Ionic Liquids. J. Chem. Eng. Data 2014, 59, 1892-1914.

31. Tariq, M.; Forte, P.; Gomes, M. C.; Lopes, J. C.; Rebelo, L., Densities and refractive indices of imidazolium-and phosphonium-based ionic liquids: Effect of temperature, alkyl chain length, and anion. J. Chem. Thermodyn. 2009, 41, 790-798.

32. Gonzalez-Miquel, M.; Bedia, J.; Palomar, J.; Rodriguez, F., Solubility and Diffusivity of $\mathrm{CO}_{2}$ in [hxmim] [NTf $\left.{ }_{2}\right],\left[\right.$ omim] $\left[\mathrm{NTf}_{2}\right]$, and [dcmim] [NTf 2 at $\mathrm{T}=(298.15,308.15$, and 323.15$) \mathrm{K}$ and Pressures up to 20 bar. J. Chem. Eng. Data 2014, 59, 212-217.

33. Corderí, S.; González, E. J.; Calvar, N.; Domínguez, Á., Application of [HMim][NTf $]$,[HMim][TfO] and [BMim] [TfO] ionic liquids on the extraction of toluene from alkanes: Effect of the anion and the alkyl chain length of the cation on the LLE. J. Chem. Thermodyn. 2012, 53, 60-66.

34. Lago, S.; Rodríguez, H.; Soto, A.; Arce, A., Deterpenation of Citrus Essential Oil by Liquid- Liquid Extraction with 1-Alkyl-3-methylimidazolium Bis (trifluoromethylsulfonyl) amide lonic Liquids. J. Chem. Eng. Data 2011, 56, 1273-1281.

35. Matsuda, H.; Norizuki, Y.; Kawai, M.; Kurihara, K.; Tochigi, K.; Ochi, K., Liquid-Liquid Equilibria for Extraction of Citrus Essential Oil Using lonic Liquids. J. Solution Chem. 2014, 43, 1561-1573.

36. Řehák, K.; Morávek, P.; Strejc, M., Determination of mutual solubilities of ionic liquids and water. Fluid Phase Equilib. 2012, 316, 17-25.

37. Currás, M. R.; Husson, P.; Padua, A. A.; Costa Gomes, M. F.; García, J., High-Pressure Densities of 2, 2, 2-Trifluoroethanol+ Ionic Liquid Mixtures Useful for Possible Applications in Absorption Cycles. Ind. Eng. Chem. Res. 2014, 53, 10791-10802.

38. Tariq, M.; Serro, A. P.; Mata, J. L.; Saramago, B.; Esperança, J. M.; Lopes, J. N. C.; Rebelo, L. P. N., High-temperature surface tension and density measurements of 1-alkyl-3-methylimidazolium bistriflamide ionic liquids. Fluid Phase Equilib. 2010, 294, 131-138.

39. Hiraga, Y.; Kato, A.; Sato, Y.; Smith Jr, R. L., Densities at Pressures up to $200 \mathrm{MPa}$ and Atmospheric Pressure Viscosities of Ionic Liquids 1-Ethyl-3-methylimidazolium Methylphosphate, 1-Ethyl-3-methylimidazolium Diethylphosphate, 1-Butyl-3-methylimidazolium Acetate, and 1Butyl-3-methylimidazolium Bis (trifluoromethylsulfonyl)imide. J. Chem. Eng. Data 2015, 60, 876885.

40. Montalbán, M.; Bolívar, C.; Díaz Baños, F. G.; Víllora, G., Effect of Temperature, Anion, and Alkyl Chain Length on the Density and Refractive Index of 1-Alkyl-3-methylimidazolium-Based lonic Liquids. J. Chem. Eng. Data 2015, 60, 1986-1996.

41. Diogo, J. C.; Caetano, F. J.; Fareleira, J. M.; Wakeham, W. A., Viscosity measurements of three ionic liquids using the vibrating wire technique. Fluid Phase Equilib. 2013, 353, 76-86.

42. Iguchi, M.; Hiraga, Y.; Sato, Y.; Aida, T. M.; Watanabe, M.; Smith Jr, R. L., Measurement of HighPressure Densities and Atmospheric Viscosities of Ionic Liquids: 1-Hexyl-3-methylimidazolium Bis(trifluoromethylsulfonyl)imide and 1-Hexyl-3-methylimidazolium Chloride. J. Chem. Eng. Data 2014, 59, 709-717.

43. Akbar, M. M.; Murugesan, T., Thermophysical properties for the binary mixtures of 1-hexyl-3methylimidazolium bis(trifluoromethylsulfonyl)imide $[\mathrm{hmim}]\left[\mathrm{Tf}_{2} \mathrm{~N}\right]+\mathrm{N}$-methyldiethanolamine (MDEA) at temperatures (303.15 to 323.15) K. J. Mol. Liq. 2012, 169, 95-101.

44. Gardas, R. L.; Freire, M. G.; Carvalho, P. J.; Marrucho, I. M.; Fonseca, I. M.; Ferreira, A. G.; Coutinho, J. A., P p T Measurements of Imidazolium-Based lonic Liquids. J. Chem. Eng. Data 2007, 52, 1881-1888.

45. Blokhin, A. V.; Paulechka, Y. U.; Strechan, A. A.; Kabo, G. J., Physicochemical properties, structure, and conformations of 1-butyl-3-methylimidazolium 
bis(trifluoromethanesulfonyl)imide C(4)mim NTf2 ionic liquid. J. Phys. Chem. B 2008, 112 (14), 4357-4364.

46. Archer, D. G., Thermodynamic Properties of 1-hexyl-3-methylimidazolium bis(trifluoromethylsulfonyl)imide. NISTIR 2006, 6645.

47. Shirota, H.; Mandai, T.; Fukazawa, H.; Kato, T., Comparison between Dicationic and Monocationic Ionic Liquids: Liquid Density, Thermal Properties, Surface Tension, and Shear Viscosity. J. Chem. Eng. Data 2011, 56 (5), 2453-2459.

48. Gomez, E.; Calvar, N.; Dominguez, A.; Macedo, E. A., Thermal Analysis and Heat Capacities of 1Alkyl-3-methylimidazolium Ionic Liquids with NTf2-, TFO-, and DCA(-) Anions. Ind. Eng. Chem. Res. 2013, 52 (5), 2103-2110.

49. Shimizu, Y.; Ohte, Y.; Yamamura, Y.; Saito, K., Effects of Thermal History on Thermal Anomaly in Solid of Ionic Liquid Compound [C4mim][Tf2N]. Chem. Lett. 2007, 36, 1484.

50. Crosthwaite, J. M.; Muldooon, M. J.; Dixon, J. K.; Anderson, J. L.; Brennecke, J. F., Phase transition and decomposition temperatures, heat capacities and viscosities of pyridinium ionic liquids. J. Chem. Thermodyn. 2005, 37, 559-568.

51. Fredlake, C. P.; Crosthwaite, J. M.; Hert, D. G.; Aki, S.; Brennecke, J. F., Thermophysical properties of imidazolium-based ionic liquids. J. Chem. Eng. Data 2004, 49 (4), 954-964.

52. Tokuda, H.; Hayamizu, K.; Ishii, K.; Susan, M. A. B. H.; Watanabe, M., Physicochemical Properties and Structures of Room Temperature Ionic Liquids. 2. Variation of Alkyl Chain Length in Imidazolium Cation. J. Phys. Chem. B 2005, 109, 6103-6110.

53. Shimizu, Y.; Ohte, Y.; Yamamura, Y.; Saito, K., Is the liquid or the solid phase responsible for the low melting points of ionic liquids? Alkyl-chain-length dependence of thermodynamic properties of C(n)mim Tf2N. Chem. Phys. Lett. 2009, 470 (4-6), 295-299.

54. Troncoso, J.; Cerdeirina, C. A.; Sanmamed, Y. A.; Romani, L.; Rebelo, L. P. N., Thermodynamic properties of imidazolium-based ionic liquids: Densities, heat capacities, and enthalpies of fusion of bmim PF6 and bmim NTf2. J. Chem. Eng. Data 2006, 51 (5), 1856-1859.

55. Blokhin, A. V.; Paulechka, Y. U.; Kabo, G. J., Formation of metastable crystals Of C(4)mim NTf2 and C(6)mim NTf2. Thermochim. Acta 2006, 445 (1), 75-77.

56. Shimizu, Y.; Ohte, Y.; Yamamura, Y.; Saito, K.; Atake, Low-Temperature Heat Capacity of RoomTemperature Ionic Liquid, 1-Hexyl-3-methylimidazolium Bis(trifluoromethylsulfonyl)imide. J. Phys. Chem. B 2006, 110, 13970-13975.

57. Hughes, T. J.; Syed, T.; Graham, B. F.; Marsh, K. N.; May, E. F., Heat Capacities and Low Temperature Thermal Transitions of 1-Hexyl and 1-Octyl-3-methylimidazolium bis(trifluoromethylsulfonyl)amide. J. Chem. Eng. Data 2011, 56 (5), 2153-2159.

58. Shevelyova, M. P.; Zaitsau, D. H.; Paulechka, Y. U.; Blokhin, A. V.; Kabo, G. J.; Verevkin, S. P.; Heintz, A., Solid-liquid equilibrium and activity coefficients for caprolactam+1-hexyl-3methylimidazolium bis(trifluoromethylsulfonyl)imide and cyclohexanone oxime+1-hexyl-3methylimidazolium bis(trifluoromethylsulfonyl)imide. J. Chem. Eng. Data 2007, 52 (4), 13601365.

59. Wachter, P.; Schreiner, C.; Schweiger, F.-G.; Gores, H. J., Determination of phase transition points of ionic liquids by combination of thermal analysis and conductivity measurements at very low heating and cooling rates. J. Chem. Thermodyn. 2010, 42 (7), 900-903.

60. Zheng, W.; Mohammed, A.; Hines, L. G., Jr.; Xiao, D.; Martinez, O. J.; Bartsch, R. A.; Simon, S. L.; Russina, O.; Triolo, A.; Quitevis, E. L., Effect of cation symmetry on the morphology and physicochemical properties of imidazolium ionic liquids. J. Phys. Chem. B 2011, 115 (20), 657284. 
61. Tariq, M.; Carvalho, P. J.; Coutinho, J. A. P.; Marrucho, I. M.; Lopes, J. N. C.; Rebelo, L. P. N., Viscosity of (C2-C14) 1-alkyl-3-methylimidazolium bis(trifluoromethylsulfonyl)amide ionic liquids in an extended temperature range. Fluid Phase Equilib. 2011, 301, 22-32.

62. Ahosseini, A.; Scurto, A. M., Viscosity of Imidazolium-Based Ionic Liquids at Elevated Pressures: Cation and Anion Effects. Int. J. Thermophys. 2008, 29, 1222-1243.

63. Rocha, M. A. A.; Neves, C. M. S. S.; Russina, O.; Triolo, A.; Coutinho, J. A. P.; Santos, L. M. N. B. F., Alkylimidazolium Based Ionic Liquids: Impact of Cation Symmetry on Their Nanoscale Structural Organization. J. Phys. Chem. B 2013, 117, 10889-10897.

64. Ahosseini, A.; Weatherley, L. R.; Scurta, A. M., Viscosity and Diffusivity for the lonic Liquid 1Hexyl-3-methylimidazolium Bis(trifluoromethylsulfonyl)amide with 1-Octene. J. Chem. Eng. Data 2011, 56, 3715-3721.

65. Chen, Z. J.; Lee, J. M., Free Volume Model for the Unexpected Effect of C2-Methylation on the Properties of Imidazolium Ionic Liquids. J. Phys. Chem. B 2014, 118, 2712-2718.

66. Calado, M. S.; Branco, A. S. H.; Diogo, J. C. F.; Fareleira, J. M. N. A., Solubility, volumetric properties and viscosity of the sustainable systems of liquid poly(ethylene glycol) 200 with imidazolium and phosphonium-based ionic liquids: Cation and Anion effects. J. Chem. Thermodyn. 2015, 80, 79-91.

67. Tokuda, H.; Tsuzuki, S.; Susan, M. A. B. H.; Hayamizu, K.; Watanabe, M., How lonic Are RoomTemperature Ionic Liquids? An Indicator of the Physicochemical Properties. J. Phys. Chem. $B$ 2006, 110, 19593-19600.

68. Diogo, J. C. F.; Caetano, F. J. P.; Fareleira, J. M. N. A.; Wakeham, W. A., Viscosity measurements of three ionic liquids using the vibrating wire technique. Fluid Phase Equilib. 2013, 353, 76-86.

69. Lopes, J. N. C.; Gomes, M. F. C.; Husson, P.; Padua, A. A. H.; Rebelo, L. P. N.; Sarraute, S.; Tariq, M., Polarity, Viscosity, and Ionic Conductivity of Liquid Mixtures Containing $\left[\mathrm{C}_{4} \mathrm{C}_{1} \mathrm{im}\right]\left[\mathrm{Ntf}_{2}\right]$ and a Molecular Component. J. Phys. Chem. B 2011, 115, 6088-6099.

70. Andreatta, A. E.; Francisco, M.; Rodil, E.; Soto, A.; Arce, A., Isobaric vapour-liquid equilibria and physical properties for isopropyl acetate + isopropanol + 1-butyl-3-methyl-imidazolium bis(trifluoromethylsulfonyl)imide mixtures. Fluid Phase Equilib. 2011, 300, 162-171.

71. Seddon, K. R., Densities of Ionic Liquid for IUPAC Project. Personal Communication 2008.

72. Seoane, R. G.; Gomez, E.; Calvar, N.; Gonzalez, E. J.; Macedo, E. A.; Dominguez, A., Temperature Dependence and Structural Influence on the Thermophysical Properties of Eleven Commercial Ionic Liquids. Ind. Eng. Chem. Res. 2012, 51, 2492-2504.

73. Yunus, N. M.; Mutalib, M. I. A.; Man, Z.; Bustam, M. A.; Murugesan, T., Thermophysical properties of 1-alkylpyridinum bis(trifluoromethylsulfonyl)imide ionic liquids. J. Chem. Thermodyn. 2010, 42, 491-495.

74. Ahosseini, A.; Ortega, E.; Sensenich, B.; Scurta, A. M., Viscosity of n-alkyl-3-methyl-imidazolium bis(trifluoromethylsulfonyl)amide ionic liquids saturated with compressed $\mathrm{CO}_{2}$. Fluid Phase Equilib. 2009, 286, 72-78.

75. McHale, G.; Hardacre, C.; Ge, R.; Doy; Allen, R. W. K.; Maclnnes, J. M.; Brown, M. R.; Newton, M. I., Density-Viscosity Product of Small-Volume Ionic Liquid Samples Using Quartz Crystal Impedance Analysis. Anal. Chem. 2008, 80, 5806-5811. 